Volume 19, 2020

\title{
TRENDS IN USING ICT RESOURCES BY PROFESSORS IN HEIS (HIGHER EDUCATION INSTITUTIONS)
}

\begin{tabular}{|c|c|c|}
\hline Carmen Ricardo-Barreto* & $\begin{array}{l}\text { Universidad del Norte, Barranquilla, } \\
\text { Colombia }\end{array}$ & cricardo@uninorte.edu.co \\
\hline Daladier Jabba Molinares & $\begin{array}{l}\text { Universidad del Norte, Barranquilla, } \\
\text { Colombia }\end{array}$ & djabba@uninorte.edu.co \\
\hline Humberto Llinás & $\begin{array}{l}\text { Universidad del Norte, Barranquilla, } \\
\text { Colombia }\end{array}$ & $\underline{\text { hllinas@uninorte.edu.co }}$ \\
\hline Judith Peña Santodomingo & $\begin{array}{l}\text { Universidad de San Buenaventura, } \\
\text { Medellín, Colombia }\end{array}$ & direccion.cideh@usbmed.edu.co \\
\hline Cinthia Astorga Acevedo & $\begin{array}{l}\text { Universidad del Norte, Barranquilla, } \\
\text { Colombia }\end{array}$ & castorga@uninorte.edu.co \\
\hline Pedro Acevedo Rodríguez & $\begin{array}{l}\text { Universidad del Norte, Barranquilla, } \\
\text { Colombia }\end{array}$ & pdacevedo@uninorte.edu.co \\
\hline Claudia Baloco Navarro & $\begin{array}{l}\text { Universidad del Norte, Barranquilla, } \\
\text { Colombia }\end{array}$ & cbaloco@uninorte.edu.co \\
\hline Sandra Villarreal Villa & $\begin{array}{l}\text { Universidad del Norte, Barranquilla, } \\
\text { Colombia }\end{array}$ & sandravillarreal@uninorte.edu.co \\
\hline
\end{tabular}

ABSTRACT

Aim/Purpose

This study aimed at recognizing and analyzing the trends of ICT use (hardware, software, and digital educational resources) by higher education professors in the Antioquia region (Colombia), and characterizing this population according to their context.

Background

The inexorable growth of ICT and the convergence of networks have produced great changes in human culture, and particularly in the educational environment. As a result, the development of appropriate technological competencies and the study of the trends of ICT use to meet this requirement become necessary.

Accepting Editor Tharrenos Bratitsis | Received: April 7, 2020 | Revised: June 28, 2020 | Accepted: July 2, 2020.

Cite as: Ricardo-Barreto, C., Jabba Molinares, D., Llinás, H, Peña Santodomingo, J., Astorga Acevedo, C., Acevedo Rodríguez, P., Baloco Navarro, C., \& Villarreal Villa, S. (2020). Trends in using ICT resources by professors in HEIs (Higher Education Institutions. Journal of Information Technology Education: Research, 19, 395-425. https://doi.org/10.28945/4601

(CC BY-NC 4.0) This article is licensed to you under a Creative Commons Attribution-NonCommercial 4.0 International License. When you copy and redistribute this paper in full or in part, you need to provide proper attribution to it to ensure that others can later locate this work (and to ensure that others do not accuse you of plagiarism). You may (and we encourage you to) adapt, remix, transform, and build upon the material for any non-commercial purposes. This license does not permit you to use this material for commercial purposes. 
Trends in Using ICT Resources by Professors in HEIs

Methodology The study follows a quantitative approach, with a non-experimental and correlational design. The sample consisted of 97 professors from different universities of the Antioquia region (Colombia), age between 21 and 60 years old, selected in a non-aleatory way, to fill in an online survey.

Contribution A contribution is the identification and characterizing of an active population in higher education and the trends in use of digital resources in the classroom from the professors' perception that allows recognizing the pedagogical potential of these resources to enrich the process of social and educational appropriation of ICT in higher education institutions (HEI).

Findings Findings show the level of use (low and high) of ICT (hardware, software, and digital educational resources) by university professors, identifying those that still maintain a predominant use (e.g., desktop PC); those that are innovative (e.g., laptop, smartphone), and those that appear with low frequency (e.g., apps, digital blackboard, clickers). These results show some factors that may influence the development of these trends, such as technological infrastructure, HEI support, teachers' training, the accessibility and availability of resources, and preference for digital open resources.

Recommendations According to the results, universities should provide technological resources and for Practitioners suitable connectivity necessary for educational innovation to professors. Besides, it is suggested to strengthen the pedagogical use of ICT by training according to the trends of use and professors' competency levels.

Recommendations This study made evident professors' great preference of using storage, display, and for Researchers sound devices, among them the desktop PC and the laptop continue being the key tools to boost the educational process, in contrast to the low use of tools to detect plagiarism, social networks, and apps to boost activities with emergent technologies. Considering the potential and richness these tools may offer in the educational processes, it should be interesting to carry out studies on factors or motivations that influence the little inclination to use them.

Impact on Society The analysis of the trends of ICT use from the perspective of university professors about hardware, software, and digital educational resources may suggest greater attention to the permanent training to take advantage of the pedagogical and technological potential of these tools.

Future Research This study allows thinking of other ways and lines of research that are the base to develop future proposals exploring the reality of new generations of professors. It also could be the base to carry out comparative studies in other regional contexts, which permit to compare, contrast and enrich professors' diversity. On the other hand, this research also shows the importance of carrying out mixed studies that offer a greater level of comprehension, analysis, and reflection about the target population and the trends of use of ICT.

Keywords hardware, software, digital educational resources, higher education institutions, ICT

\section{INTRODUCTION}

In most countries, education systems face the challenge of using Information and Communication Technologies (ICT) and, at the same time, assuming the evolution of these to offer tools and knowledge necessary for the 21 st century to the community (Scott, 2015). Thus, collaborative efforts have been carried out among international organisms (Instituto Nacional de Tecnologías Educativas y de Formación del Profesorado [INTEF], 2017; International Society for Technology in Education 
[ISTE], 2009; Organisation for Economic Co-operation and Development [OECD], 2019b) to intervene, systematize, and apply necessary actions to assess, use, and improve ICT suitably. As a result, there are proposals of standards and indicators about technological knowledge, abilities, and competencies that students, professors, and directives/managers of educative institutions should meet (Ferrari et al., 2014; Ministerio de Educación Nacional [M.E.N.], 2013). As a consequence, it is expected that the use of ICT strengthens the competencies needed by professors to get the optimal development of their pedagogical practice (Aydin et al., 2019; Somekh, 2008). This implies the analysis of trends of ICT use to recognize the pedagogical potential of ICT supporting and enriching the educational dynamics (Silber-Varod et al., 2019).

Some studies about ICT (Amhag et al., 2019; Duță \& Martínez-Rivera, 2015; Melo et al., 2018; Mirete, 2016; M. T. Padilla et al., 2016; Tapia et al., 2017; Voogt \& Roblin, 2012) show the relevance and necessity to continue carrying out works on the use of digital tools by professors, and the subsequent needs of digital competencies in higher education. Cabero (2014), Cobo (2011), and Coll (2013) have developed relevant work lines on educational technologies and professors' development concerning the use of these technologies that have steady dynamics. Ungar and Baruch (2016) claim that professors have a fundamental role in training and teaching based on ICT. Considering that ICT tools are used in many ways and are continually changing, it is necessary to study, develop, and discuss the use of digital tools in education. In the face of this, professors' role in ICT-based training and teaching is fundamental (Amhag et al., 2019; Bradshaw \& Howard, 2019). Maksimović and Dimić (2016), Avalos (2011), and Sánchez-García et al. (2015) agree in that innovative solutions are required to be applied in professors professional development with the use of ICT, so it is very important to consider the role of the professors and professors-student relations, in the face of the complex changes of these relations. In the same way, Kluzer \& Pujol Priego (2018), Tapia et al. (2017), Salinas (2004) and Engen (2019) state that the use of ICT by professors requires an in-depth study of how technologies are used in a strategic, innovative, and purposeful way, so that teaching processes have real changes beneficial for learning.

In this sense, the development of suitable technological competencies is necessary to deal with an increasingly diverse, complex, and demanding context in a proper way (Cabero, 2014; Falcó \& Minguell, 2016; Salinas, 2004). Thus, Higher Education Institutions (HEI) should implement the learning with technology to generate additional educational values (Dabbagh et al., 2019; Fischer et al., 2015; Torres et al., 2018), having in mind that integrating ICT in the institutions fosters a new learning culture (OECD, 2019a; Prendes, 2011; Vázquez-Cano \& Sevillano-García, 2015; Zhao et al., 2016). At the same time, concepts involving not only physical and logical aspects, but also cognitive and social ones, based on technical and cultural developments of trends, are being developed, such as internet (Castells, 2005), web (Grande et al., 2016), e-learning (Alshwaier et al., 2012; Njenga \& Fourie, 2010), self-education (Kruchinin et al., 2018; Panadero, 2017), mobile technology (Rossing et al., 2012), and emergent technologies (Adell \& Castañeda, 2012; Almeida \& Simoes, 2019; BarrosoOsuna et al., 2019; Prinsloo \& Van Deventer, 2017).

This research aims at recognizing the trends of ICT use in a university context in the region of Antioquia (Colombia), showing the characterization of the professor population and the identification of the use of technological tools in their academic activity. In the study, three a-priori categories are considered - Hardware, Software, and Digital Educational Resources (DER) - which are grouped in sub-categories associated with characteristics of use and functioning within the digital devices to facilitate their study and answer the research question. This paper shows results from a descriptive, correlational, and factorial analysis, validating the categories of the instrument applied to the target population of the study. 


\section{REVIEW OF THE LITERATURE}

\section{ICT USE IN HIGHER EDUCATION}

To study the integration of ICT to the university context, the framework of competencies, abilities, and attitudes considered by the M.E.N. (2013) is adopted. It incorporates pedagogical and technological practices that provide a formative approach. These also help to consolidate the value of permanent, multidisciplinary, and long-life learning. In this regard, it is considered that the training of the educator should be oriented towards the generation of reflections on processes aimed at promoting the pedagogical use of tools, resources, programs, services, and environments characterized by the appropriate use of technology, and to produce processes of pedagogical innovation (Cobo, 2011; Iriarte et al., 2017).

The impact and trend of ICT in higher education to identify and improve the professor competencies have been a topic of multiple research at international level (Carpenter et al., 2019; Dorfsmani, 2015; Eshet -Alkalai, \& Soffer, 2012; Voogt \& Roblin, 2012) and in Colombia (M.E.N., 2013; J. E. Padilla et al., 2014; Rodríguez et al., 2014). They have defined guidelines to deal with the worry about ICT competencies as a complex process that depends on political, academic, social, and individual factors. In this process professors play an important role. However, this study focuses on identifying the trends of ICT use of professors in university classrooms.

As regards to this, Qasem and Viswanathappa (2016) and Mahdum et al. (2019) state that the use and appropriation of ICT in classrooms represent complex processes. They do not only depend on the quality of the infrastructure and provision or the access to resources, but also on the interest and appropriation of professors to use them pedagogically to improve their classroom work, and thus to obtain students' significant learning (Anaya et al. 2012; Morffe, 2010; Salinas, 2004). This requires the development of detailed studies that give an account of the context reality. Hence, the instrument used in this study included the characterization of the target population and the identification of trends of use grouped in three categories: hardware, software, and DER.

\section{HARDWARE}

This category deals with the identification of hardware tools according to their characteristics and functions, such as touch devices and devices of storing, audio, and video (Gallego, 2019; Ward, 2011). The touch devices, recognized as recent technologies and adopted in educational contexts (Becker et al., 2017), include:

- Digital boards, which allow interacting with digital contents during a projection, making it easy the handling of educational resources (Marcelo et al., 2016; Ramos \& Abad, 2016), and clickers, small devices that sends answers to a single receptor. Both devices make possible students' improvement, motivation, and participation in the classroom (Camacho-Miñano \& Del Campo, 2016).

- Wearables, tablets, and smartphones, as supporting devices in the classroom, permit boosting professor-learning processes (Robles et al., 2012, 2019; Vázquez-Cano \& Sevillano-García, 2015). They offer a high variety of interactions with academic environments enabling the learning, collaboration, and interchange of ideas among those involved (Abascal \& Moriyon 2002; Al-Emran et al., 2016). HEIs are in a change of paradigm from a model of transference of knowledge to an active and self-directed collaborative model. The portability of these devices favor student independent study (Majeed \& Ali, 2018; Mang \& Wardley, 2019).

The second group includes:

- USB memory, which permits storing of information in a portable way and access without the need of connecting to the web. This is an advantage, particularly in those HEI that face 
problems of access to the internet due to different factors such as infrastructure or geographical location (Sánchez, 2015);

- Video projectors and speakers for presenting visual material in the classroom, strengthening the interaction with contents developed in the class. Devices in this group are considered as basic and/or traditional tools in a university classroom because they permit the direct connection with multimedia contents (Alvarado et al. 2013; Carvajal et al., 2018);

- Desktop PC, considered as one of the essential and pertinent tools to develop the professor pedagogical practice (Georgina \& Hosford, 2009; Noriega et al., 2014);

- Laptops (Bautista et al. 2013; Kay \& Lauricella, 2016; Sáez-López et al., 2019);

- Mobile devices (Crompton \& Burke, 2018; Loague et al., 2018).

\section{SOFTWARE}

This category includes software tools proposed by authors such as Watson et al. (2015) who have organized them in sub-categories according to their functionality. Mirete (2016) states that according to the design of educational situations, the variety of software offers possibilities to generate new and diverse learning experiences. Nevertheless, it must be borne in mind that professors, in the educational activity, are becoming learning facilitators and students are playing a more active role in the construction of their knowledge (Peeraer \& Van Petegem, 2011). This feature leaves behind the merely informative function that some professors assume, and which is not as effective as more active methods (Prendes, 2011).

Recently, most HEIs have an essential infrastructure as a digital technological base (Tok \& Sora, 2013) where software has become an indispensable element to improve learning processes (Peeraer \& Van Petegem, 2011). This implies an integrating vision of ICT with educational strategies, contents, activities, and curriculum in general (Stensaker et al., 2007).

Some sub-categories have been identified in this category. One of them, tools to organize the agenda, which facilitate teamwork between professors and students. Another is software to create interactive presentations. Although little is known about the professors' experience regarding such creations, some authors have identified the professors' work from the tools and preferences of these applications in their pedagogical acts (Burke et al., 2009; Gupta, 2011; Hein, 2014). Another sub-category considered refers to tools for:

- creating and editing videos,

- sharing, managing, and creating information,

- editing images,

- creating digital material such as stories, comics, books, or magazines.

The production of content by using these tools represents a significant advance in the generation of digital content by professors. This means greater university commitment and dedication providing tools that facilitate this work (Berenguer \& Molina, 2016).

Another group of sub-categories involves tools or apps for:

- creating mind maps and computer graphics,

- boosting videoconferences,

- boosting activities and exercises with gamification,

- strengthening exercises with augmented reality,

- detecting plagiarism.

This last group of tools highlights digital competencies related to the production of digital contents and learning environments that place the professor at an innovative level (M.E.N., 2013). In this way, the way to active learning and the intensification of competencies for the students is widened (Trujillo, 2014). 


\section{DIGITAL EDUCATIONAL RESOURCES}

This category includes Digital Educational Resources (DER), considered as flexible, usable, and granular digital materials in diverse formats with a pedagogical intention. They facilitate the achievement of learning objectives and adapt to the needs, particularities, and interests of actors involved in the educational activity (Iriarte et al., 2015; Kluzer \& Pujol Priego, 2018; M.E.N., 2012; Zapata, 2012). These DER have been grouped by Gallego (2019) according to their characteristic and functionality, such as:

- Digital repositories: involves virtual image database, virtual space with a database of strategies, resources, and digital walls.

- Multimedia resources, Wiki, and LMS: include blogs, video, interactive virtual platforms, and social networks.

According to Abella-García et al. (2019), Al-Azawei (2019), Sáez-López et al. (2019), Astorga et al., (2017) and Manca \& Ranieri (2017), the DER:

- facilitate the development of pedagogical activities,

- favor and reinforce learning and competencies, and enable their assessment,

- foster content comprehension,

- promote self-learning, teamwork, participation, attention, and critical attitudes,

- offer the possibility to share and interact with others to generate networks.

\section{RESEARCH QUESTION}

This study aimed to answer the question:

What is the trend of use of hardware, software, and Digital Educational Resources by higher education professors in the Antioquia region (Colombia)?

\section{METHOD}

The study has a quantitative approach, with a non-experimental design that allows observing and analyzing the phenomena of the study in the way they occur without any modification or manipulation, and co-relational because it aims at identifying the degree of association of the different variables and categories linked to the research (Hernández et al., 2014). The next sections describe the sample and identify details of the instrument used.

\section{CONTEXT AND SAMPLE}

The socio-demographic characteristics of the participating professors in the Antioquia region (Colombian Andean region) are presented below.

- Ninety-seven professors participated, of whom 32 were women (34 per cent) and 65 were men (66 per cent).

- Forty-two per cent of the teachers were aged between 31 and 40 , while $33 \%$ were aged between 41 and 50.

- In relation to the area of knowledge that the participants guide, $30 \%$ are in areas related to Economics, Administration, and Accounting, followed by Social and Human Sciences with $24 \%$.

- In addition, years of dedication to university teaching were identified, with 6 to 10 years corresponding to $27 \%$, followed by 16 to 20 years with $18 \%$.

The sample was selected in a non-random way. The participants signed an informed consent form to participate in the study. In order to carry out the validity of the scales through factor analysis, criterion 8:1 was considered, that is, to have at least eight participants per item, as recommended by some 
authors (Bishop, 2008; Kline, 2011; Thorndike, 1995) and applied by some studies (Bentler \& Chou, 1987; Costello \& Osborne, 2005; Saunders \& Huynh, 1980; Yurdugul, 2008).

\section{INSTRUMENT}

Participant professors answered an online questionnaire based on the one designed by Astorga and Ricardo (2014) and adapted from the M.E.N. (2013). It has been adjusted for use in this study. The questionnaire is divided into three categories whose response options are of the Likert type and range from 1 to 5 ( $1=$ Never; $2=$ Seldom; $3=$ Sometimes; $4=$ Often; and $5=$ Always). These questions allow us to measure university professors' level of appropriation of different ICT. One of the categories of the instrument (called Hardware) consists of 13 sub-categories; the second one (Software), of 17 sub-categories, and the third (Digital Educational Devices-DER), of 8 sub-categories.

\section{STATISTICAL ANALYSIS}

First, basic descriptive statistics were calculated. Similarly, the corresponding tables are presented to analyze the distributional behavior of the data collected. Then, the correlation matrix of the sub-categories of the instrument was constructed to analyze the level of association among them. As we have an instrument with ordinal Likert scales, the analyses developed were carried out with polychoric correlation matrixes (Domínguez, 2014; Freiberg et al., 2013; Lloret-Segura et al., 2014).

Subsequently, an exploratory factorial analysis was applied to find the factors in which the sub-categories are grouped. To do that, we first tested the underlying basic assumptions (Bartlett's sphericity and KMO test). It is important to mention that the Varimax rotation was used to find the factorial structure. Finally, the Cronbach alpha and Omega McDonalds were used for the internal consistency of the survey items (Campo-Arias \& Oviedo, 2008; Cortina, 1993; McDonald, 1999; Trizano-Hermosilla, \& Alvarado, 2016; Ventura-León \& Caycho-Rodríguez, 2017; Yang \& Green, 2011).

\section{SOFTWARE}

The program R 3.5., in particular, the packages (1) likert, version 1.3.5 (Bryer \& Speerschneider, 2016), for the Analysis and Visualization of Likert items; (2) psych, version 1.8.12 (Revelle, 2018), for the estimation of internal consistency statistics, and (3) polycor, version 0.7-10 (Fox, 2019) for the calculation of polychoric matrixes were used.

\section{RESULTS}

\section{DESCRIPTIVE STATISTICS}

\section{Descriptive statistics of the Hardware category}

Table 1 shows the percentage distribution of response levels in the Hardware category. The first column of the Table corresponds to sub-categories and the code used in the program R; the next column shows cumulative response rates.

The sub-categories with the higher cumulate percentage of response "often" or "always" are, in order, Laptop (Frec.TIC.P10.2, 86.60\%), Desktop PC (Frec.TIC.P10.1, 76.29\%), and Smartphone (Frec.TIC.P10.9, 76.29\%). On the other hand, the sub-categories with higher cumulate percentage of response "never" or "seldom" are, in order, Clickers (Frec.TIC.P10.12, 82,47\%), Smartwatch (Frec.TIC.P10.10, 74,23\%), and Digital board (Frec.TIC.P10.8, 74,23\%). It is worth noting that the sub-category "computer room" refers to a space organized with hardware mainly for the development of lessons. These spaces are assigned previously to classes developing practical activities. As a consequence, results show that a higher percentage of response corresponds to "sometimes" with $32 \%$. 
Trends in Using ICT Resources by Professors in HEIs

Table 1. Percentage distribution of response levels in the Hardware category

\begin{tabular}{|l|l|c|c|c|c|c|}
\hline \multicolumn{2}{|c|}{ Sub-categories } & \multicolumn{5}{c|}{ Percentage (\%) } \\
\hline \multicolumn{1}{|c|}{ Name } & \multicolumn{1}{|c|}{ Code } & Never & Seldom & Sometimes & Often & Always \\
\hline 1. Desktop PC & Frec.TIC.P10.1 & 7,22 & 8,25 & 8,25 & 10,31 & 65,98 \\
\hline 2. Laptop & Frec.TIC.P10.2 & 2,06 & 0,00 & 11,34 & 41,24 & 45,36 \\
\hline 3. Video projector & Frec.TIC.P10.3 & 3,09 & 2,06 & 23,71 & 35,05 & 36,08 \\
\hline 7. Tablet/Ipad & Frec.TIC.P10.7 & 23,71 & 20,62 & 26,80 & 20,62 & 8,25 \\
\hline 8. Digital board & Frec.TIC.P10.8 & 51,55 & 22,68 & 18,56 & 5,15 & 2,06 \\
\hline 9. Smartphone & Frec.TIC.P10.9 & 6,19 & 8,25 & 9,28 & 21,65 & 54,64 \\
\hline 10. Smartwatch & Frec.TIC.P10.10 & 64,95 & 9,28 & 12,37 & 8,25 & 5,15 \\
\hline 11. Computer room & Frec.TIC.P10.11 & 16,49 & 20,62 & 32,99 & 20,62 & 9,28 \\
\hline 12. Clickers & Frec.TIC.P10.12 & 69,07 & 13,40 & 13,40 & 4,12 & 0,00 \\
\hline $\begin{array}{l}\text { 13. Photographic and } \\
\text { video Camera }\end{array}$ & Frec.TIC.P10.13 & 31,96 & 20,62 & 22,68 & 20,62 & 4,12 \\
\hline $\begin{array}{l}\text { 14. Laser pointer for } \\
\text { presentations }\end{array}$ & Frec.TIC.P10.14 & 35,05 & 18,56 & 16,49 & 18,56 & 11,34 \\
\hline 15. USB memory & Frec.TIC.P10.15 & 4,12 & 10,31 & 16,49 & 30,93 & 38,14 \\
\hline 16. Speakers & Frec.TIC.P10.16 & 9,28 & 7,22 & 35,05 & 35,05 & 13,40 \\
\hline
\end{tabular}

\section{Descriptive statistics of the Software category}

Table 2 shows the percentage distribution of response levels in the Software category. The first column of the Table corresponds to sub-categories and the code used in the program R; the next column shows cumulative response rates.

Table 2. Percentage distribution of response levels in the Software category

\begin{tabular}{|l|c|c|c|c|c|c|}
\hline \multicolumn{2}{|c|}{ Sub-categories } & \multicolumn{5}{c|}{ Percentage (\%) } \\
\hline Name & Code & Never & Seldom & Sometimes & Often & Always \\
\hline 4. Web browser & Frec.TIC.P10.4 & 1,03 & 0,00 & 2,06 & 30,93 & 65,98 \\
\hline 5. E-mail & Frec.TIC.P10.5 & 1,03 & 0,00 & 1,03 & 17,53 & 80,41 \\
\hline 6. Instant messaging/chat & Frec.TIC.P10.6 & 4,12 & 2,06 & 16,49 & 28,87 & 48,45 \\
\hline 17. Discussion forums & Frec.TIC.P10.17 & 8,25 & 14,43 & 43,30 & 20,62 & 13,40 \\
\hline $\begin{array}{l}\text { 18. Tools for organizing } \\
\text { agenda (e.g., Google Calendar, } \\
\text { Doodle) }\end{array}$ & Frec.TIC.P10.18 & 7,22 & 5,15 & 19,59 & 28,87 & 39,18 \\
\hline $\begin{array}{l}\text { 19. Tools for creating interac- } \\
\text { tive presentations (e.g., Socra- } \\
\text { tive, Mentimeter, Prezi, Wix) }\end{array}$ & Frec.TIC.P10.19 & 24,74 & 16,49 & 26,80 & 18,56 & 13,40 \\
\hline
\end{tabular}


Ricardo-Barreto, Jabba Molinares, Llinás, Peña Santodomingo, Astorga Acevedo, Acevedo Rodríguez, Baloco Navarro, \& Villarreal Villa

\begin{tabular}{|c|c|c|c|c|c|c|}
\hline \multicolumn{2}{|l|}{ Sub-categories } & \multicolumn{5}{|c|}{ Percentage $(\%)$} \\
\hline $\begin{array}{l}\text { 20. Tools for creating and ed- } \\
\text { iting videos (e.g., GoAnimate, } \\
\text { Powtoon, Movie Maker) }\end{array}$ & Frec.TIC.P10.20 & 26,80 & 26,80 & 31,96 & 10,31 & 4,12 \\
\hline $\begin{array}{l}\text { 21. Tools for sharing, manag- } \\
\text { ing, and creating information } \\
\text { (e.g., Google Drive, Dropbox) }\end{array}$ & Frec.TIC.P10.21 & 2,06 & 4,12 & 21,65 & 37,11 & 35,05 \\
\hline $\begin{array}{l}\text { 22. Tools for editing images } \\
\text { (e.g., PicMonkey) }\end{array}$ & Frec.TIC.P10.22 & 32,99 & 19,59 & 36,08 & 7,22 & 4,12 \\
\hline $\begin{array}{l}\text { 23. Tools for creating digital } \\
\text { material such as stories, com- } \\
\text { ics, books or magazines (e.g., } \\
\text { Calameo, issuu, flipsnack, Sto- } \\
\text { rybird) }\end{array}$ & Frec.TIC.P10.23 & 49,48 & 18,56 & 21,65 & 8,25 & 2,06 \\
\hline $\begin{array}{l}\text { 24. Tools for creating } \\
\text { mind/idea maps (e.g., Mind- } \\
\text { meister, Mindomo, } \\
\text { BUBBL.US) }\end{array}$ & Frec.TIC.P10.24 & 34,02 & 18,56 & 22,68 & 16,49 & 8,25 \\
\hline $\begin{array}{l}\text { 25. Tools for creating com- } \\
\text { puter graphics (e.g., Canva, } \\
\text { Piktochart, Easelly, Genially) }\end{array}$ & Frec.TIC.P10.25 & 45,36 & 13,40 & 29,90 & 9,28 & 2,06 \\
\hline $\begin{array}{l}\text { 26. Tools for boosting vide- } \\
\text { oconferences (e.g., Google } \\
\text { Hangouts, Skype) }\end{array}$ & Frec.TIC.P10.26 & 14,43 & 11,34 & 42,27 & 19,59 & 12,37 \\
\hline $\begin{array}{l}\text { 27. App for boosting activi- } \\
\text { ties / exercises with Gamifica- } \\
\text { tion (e.g., Classdojo, Mine- } \\
\text { craft) }\end{array}$ & Frec.TIC.P10.27 & 57,73 & 17,53 & 17,53 & 5,15 & 2,06 \\
\hline $\begin{array}{l}\text { 28. App for boosting activi- } \\
\text { ties/exercises with Robotics } \\
\text { (e.g., Scratch, Bee-bot) }\end{array}$ & Frec.TIC.P10.28 & 74,23 & 15,46 & 7,22 & 2,06 & 1,03 \\
\hline $\begin{array}{l}\text { 29. App for boosting activi- } \\
\text { ties/exercises with Aug- } \\
\text { mented Reality (e.g., Quiver, } \\
\text { AR Flashcards Animal Alpha- } \\
\text { bet) }\end{array}$ & Frec.TIC.P10.29 & 78,35 & 14,43 & 6,19 & 1,03 & 0,00 \\
\hline $\begin{array}{l}\text { 30. Tools for detecting plagia- } \\
\text { rism (e.g., Turnitin) }\end{array}$ & Frec.TIC.P10.30 & 20,62 & 10,31 & 29,90 & 23,71 & 15,46 \\
\hline
\end{tabular}

The sub-categories with higher cumulate percentage of response "often" or "always" are, in order, E-mail (Frec.TIC.P10.5, 97,94\%), Internet browser (Frec.TIC.P10.4, 96,91\%), and Instant messaging/chat (Frec.TIC.P10.6, 77,32\%). On the other hand, the sub-categories with the higher cumulate percentage of response "never" or "seldom" are, in order, App for boosting activities/exercises with Augmented Reality (Frec.TIC.P10.29, 92,78\%), App for boosting activities/exercises with Robotics 
Trends in Using ICT Resources by Professors in HEIs

(Frec.TIC.P10.28, 75,26\%), and Tools for creating digital material such as stories, comics, books or magazines (Frec.TIC.P10.23, 68,04\%).

\section{Descriptive statistics of the DER category}

Table 3 shows the percentage distribution of response levels in the Digital Educational Resources category. The first column of the Table corresponds to sub-categories and the code used in the program R; the next column shows cumulative response rates.

Table 3. Percentage distribution of response levels in the DER category

\begin{tabular}{|c|c|c|c|c|c|c|}
\hline \multicolumn{2}{|l|}{ Sub-categories } & \multicolumn{5}{|c|}{ Percentage $(\%)$} \\
\hline Name & Code & Never & Seldom & Sometimes & Often & Always \\
\hline $\begin{array}{l}\text { 1. Video (e.g., youtube, educa- } \\
\text { tube.es) }\end{array}$ & Frec.RED.P11.1 & 1,03 & 4,12 & 23,71 & 41,24 & 29,90 \\
\hline $\begin{array}{l}\text { 2. Virtual image database (e.g., } \\
\text { Pinterest, Freepik). }\end{array}$ & Frec.RED.P11.2 & 16,49 & 13,40 & 29,90 & 27,84 & 12,37 \\
\hline $\begin{array}{l}\text { 3. Interactive virtual platform } \\
\text { (e.g., Webquest, Edmodo, Edu- } \\
\text { caplay, Geogebra, Quizizz, } \\
\text { Jclic, Kahoot!) }\end{array}$ & Frec.RED.P11.3 & 28,87 & 16,49 & 25,77 & 13,40 & 15,46 \\
\hline 4. Wikis (e.g., Wikia) & Frec.RED.P11.4 & 37,11 & 17,53 & 25,77 & 13,40 & 6,19 \\
\hline $\begin{array}{l}\text { 5. Social networks (e.g., Insta- } \\
\text { gram, Twitter, Facebook) }\end{array}$ & Frec.RED.P11.5 & 19,59 & 16,49 & 25,77 & 21,65 & 16,49 \\
\hline 6. Blogs (e.g., WordPress) & Frec.RED.P11.6 & 34,02 & 24,74 & 18,56 & 13,40 & 9,28 \\
\hline $\begin{array}{l}\text { 7. Virtual space with database } \\
\text { of strategies, resources, and } \\
\text { others (e.g., REDEI, au- } \\
\text { laPlaneta) }\end{array}$ & Frec.RED.P11.7 & 46,39 & 17,53 & 16,49 & 13,40 & 6,19 \\
\hline $\begin{array}{l}\text { 8. Digital walls (e.g., Padlet, Mu- } \\
\text { rally, Lino, Symbaloo) }\end{array}$ & Frec.RED.P11.8 & 62,89 & 15,46 & 12,37 & 5,15 & 4,12 \\
\hline
\end{tabular}

The sub-categories with the higher cumulate percentage of response "often" or "always" are, in order, Video (Frec.RED.P11.1, 71,14\%), Virtual image database (Frec.RED.P11.2, 40,21\%), and Social networks (Frec.RED.P11.5, 38,14\%). On the other hand, the sub-categories with the higher cumulate percentage of response "never" or "seldom" are, in order, Digital walls (Frec.RED.P11.8, 78,35\%), Virtual space with a database of strategies, resources, and others (Frec.RED.P11.7, 63,92\%), Blogs (Frec.RED.P11.6, 58,76\%).

\section{CORRELATIONS BETWEEN CATEGORIES}

As there were ordinal polychoric responses in the sub-categories, the correspondent matrixes were calculated. In the figures, the squares representing very low correlations fade out as the value approaches zero. The results for each category are presented below.

\section{Correlations between Hardware sub-categories}

Figure 1 shows the correlations between the sub-categories of the Hardware category and the heat map for them. The sub-categories Desktop PC (Frec.TIC.P10.1), Laptop (Frec.TIC.P10.2), Smartphone (Frec.TIC.P10.9), Computer room (Frec.TIC.P10.11), Photo and video camera (Frec.TIC.P10.13), and Laser pointer for presentations (Frec.TIC.P10.14) have very low (less than 
0.3) polychoric correlations between them and between the others. For this reason, only the results related to the rest of the sub-categories are presented. The corresponding correlation matrix and the respective heat map are shown below.

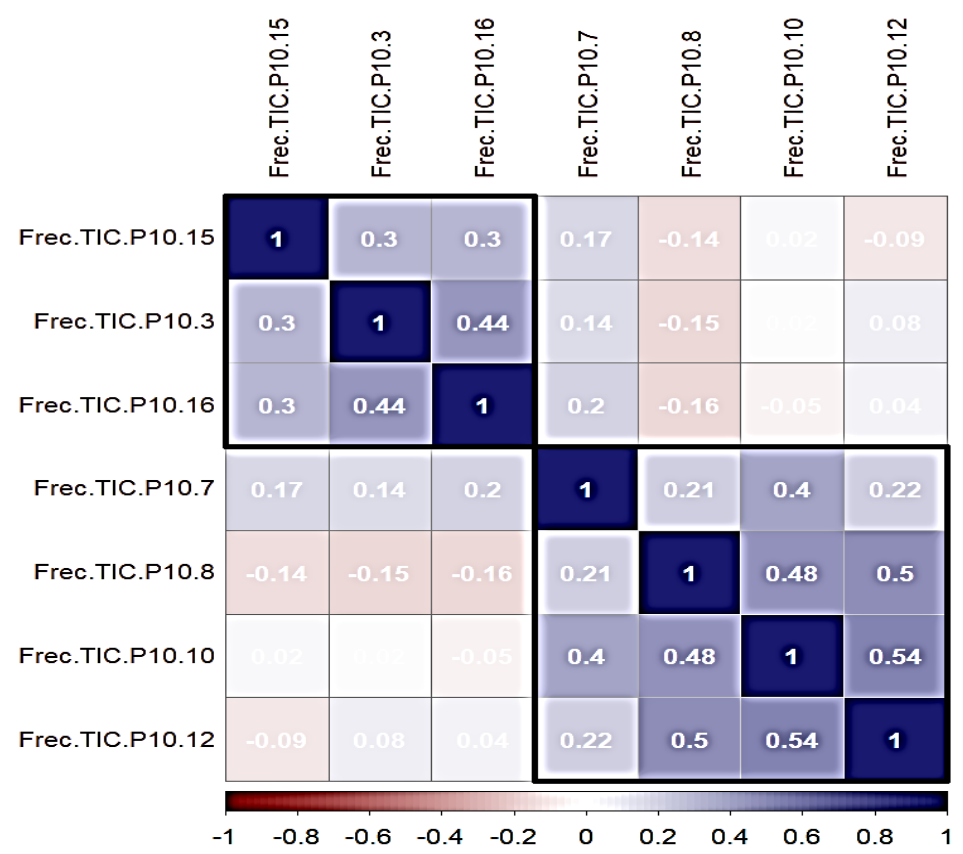

Figure 1. Heat map of polychoric correlation matrix between Hardware sub-categories

In Figure 1, we can observe that the sub-categories that have positive correlations (greater than 0) are grouped into two factors.

The first corresponds to touch and/or wireless devices, made up of the sub-categories Tablet/Ipad (Frec.TIC.P10.7), Digital board (Frec.TIC.P10.8), Smartwatch (Frec.TIC.P10.10), and Clickers (Frec.TIC.P10.12). The second group, identified as storage, display and sound devices, includes Video projector (Frec.TIC.P10.3), USB memory (Frec.TIC.P10.15), and Speakers (Frec.TIC.P10.16). According to the percentage distribution shown in Table 1, the sub-categories of the first group can be identified as those that are little used by professors, and the ones of the second group are those frequently used.

\section{Correlations between Software sub-categories}

Figure 2 shows the correlations between the sub-categories of the Software category and the heat map for them. For the factorial analysis, the "Tools for detecting plagiarism" sub-category

(Frec.TIC.P10.30) was not taken into account since its correlation with the others is small (less than $0.30)$.

In this case, it can be observed that the sub-categories of this instrument can be grouped into three factors. The first factor, called Tool for creating and editing educational materials would be made up of Tools for creating and editing videos (Frec.TIC.P10.20), Tools for editing images

(Frec.TIC.P10.22), Tools for creating digital material such as stories, comics, books or magazines (Frec.TIC.P10.23), Tools for creating computer graphics (Frec.TIC.P10.25), App to boost activities/exercises with Gamification (Frec.TIC.P10.27), App to boost activities/exercises with Robotics (Frec.TIC.P10.28), and App to boost activities/exercises with Augmented Reality (Frec.TIC.P10.29). The second factor, understood as Interaction, messaging and network storage tools, is made up of Internet browser (Frec.TIC.P10.4), E-mail (Frec.TIC.P10.5), Instant messaging/chat 
Trends in Using ICT Resources by Professors in HEIs

(Frec.TIC.P10.6), Tools for organizing the agenda (Frec.TIC.P10.18), and Tools for sharing, managing and creating information (Frec.TIC.P10.21). The third one, conceived as Tools for the organization, presentations, and collaborative work, is made up of the sub-categories Discussion forums (Frec.TIC.P10.17), Tools for creating interactive presentations (Frec.TIC.P10.19), tools for creating mind/ideas maps (Frec.TIC.P10.24), and Tools for boosting videoconferences (Frec.TIC.P10.26). Considering the percentage distribution described in Table 2, the sub-categories of the first factor can be identified as those that are little used by professors, and the ones of the second factor are those frequently used. There is no strong correlation between the sub-category Tools for detecting plagiarism (Frec.TIC.P10.30).
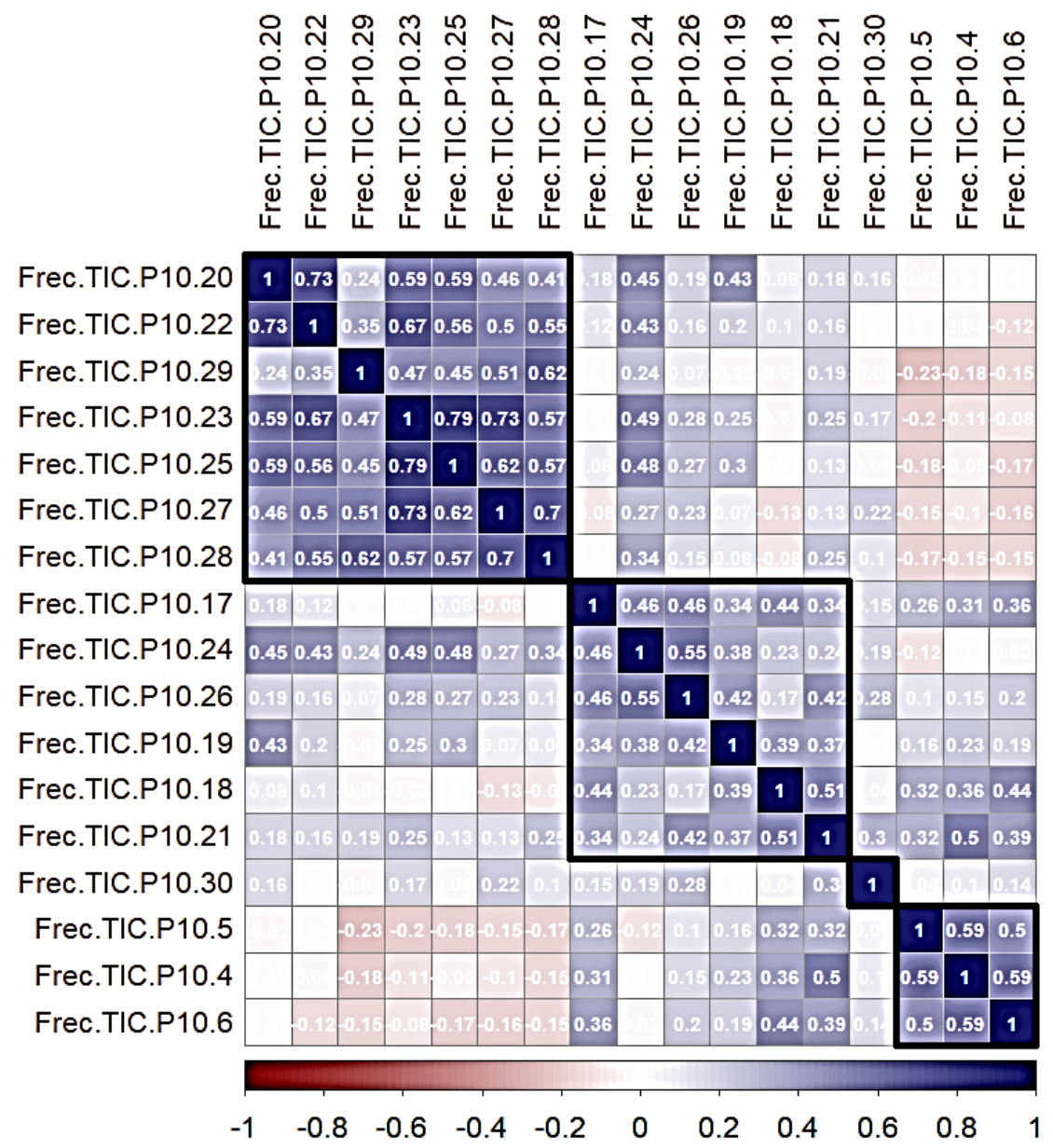

Figure 2. Heat map of the matrix of polychoric correlations between Software sub-categories.

\section{Correlations between DER sub-categories}

Figure 3 shows the correlations between the sub-categories of the DER category and the corresponding heat map for them. The Social networks sub-category (Frec.TIC.P11.5) is identified as one of the sub-categories that were not considered given the low correlations with others. 


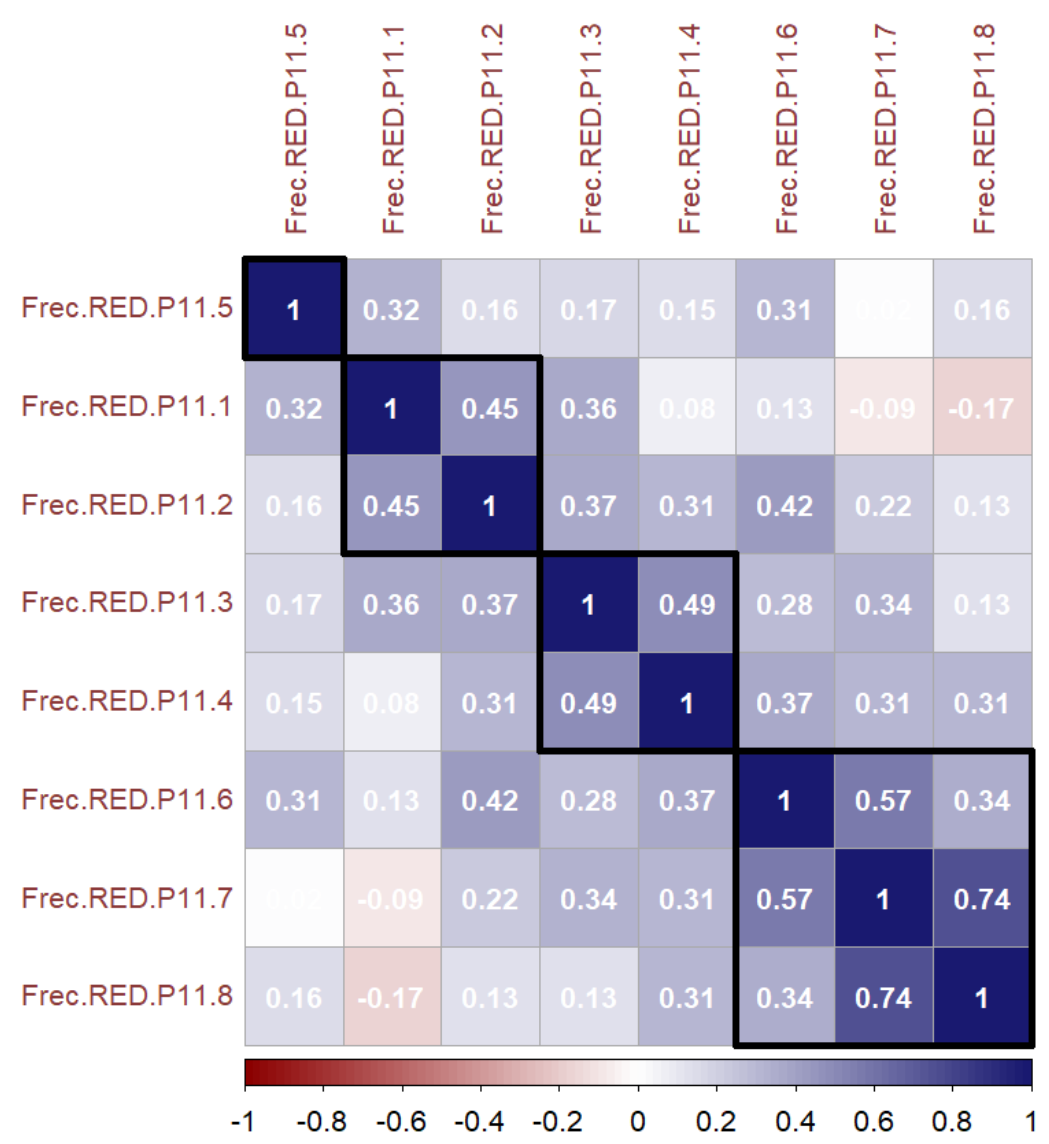

Figure 3. Heat map of the matrix of polychoric correlations between DER sub-categories.

In Figure 3 it can be observed two factors that group the seven sub-categories of this instrument whose correlations within each group are positive (greater than 0 ). The first one, called Digital repository, would be made up of Blogs(Frec.TIC.P11.6), Virtual spaces with strategy and resource bank, and others (Frec.TIC.P11.7), and Digital walls (Frec.TIC.P11.8); and the second one, called Multimedia resources, Wiki and LMS, is made up of Video (Frec.TIC.P11.1), Virtual image bank(Frec.TIC.P11.2), Interactive virtual platform (Frec.TIC.P11.3), and Wikis (Frec.TIC.P11.4). From the percentage distribution described in Table 3, it is mentioned that the sub-categories that are part of both factors are identified as those little used by the professor; except for the video that is the most used.

\section{FACTORIAL ANALYSIS}

As there are three categories with ordinal Likert scales, the analysis developed was carried out with polychoric correlation matrixes. Considering that the two basic assumptions (Bartlett's Sphericity test and significance of KMO) are always fulfilled, it can be concluded that there is a sufficient level of multicollinearity between the corresponding sub-categories and the analysis can be carried out for each scale. To determine the factorial models, the varimax rotation was applied. The factorial analyses performed for each category are detailed below.

\section{Factorial structure for the set of Hardware sub-categories}

It was found that seven sub-categories of the Hardware category can be grouped into the two factors shown in Table 4. 
Trends in Using ICT Resources by Professors in HEIs

Table 4. Factorial analysis of Hardware sub-categories

\begin{tabular}{|c|l|c|c|c|}
\hline \multicolumn{1}{|c|}{ Factors } & \multicolumn{1}{|c|}{ Sub-categories } & Factor 1 & Factor 2 & Communalities \\
\hline \multirow{4}{*}{\begin{tabular}{c} 
Factor 1 $\begin{array}{c}\text { Touch and Wireless } \\
\text { devices }\end{array}$ \\
\cline { 2 - 5 }
\end{tabular}} & Frec.TIC.P10.7 & 0.42 & 0.29 & 0.26 \\
\cline { 2 - 5 } & Frec.TIC.P10.8 & 0.67 & -0.24 & 0.50 \\
\cline { 2 - 5 } & Frec.TIC.P10.10 & 0.78 & 0.02 & 0.61 \\
\hline \multirow{2}{*}{$\begin{array}{c}\text { Factor 2 Storage, display and } \\
\text { sound devices }\end{array}$} & Frec.TIC.P10.3 & 0.03 & 0.00 & 0.47 \\
\cline { 2 - 5 } & Frec.TIC.P10.15 & -0.03 & 0.48 & 0.40 \\
\cline { 2 - 5 } & Frec.TIC.P10.16 & -0.01 & 0.67 & 0.23 \\
\hline \multicolumn{2}{|r|}{ Percentage of Variance explained } & $24 \%$ & $17 \%$ & Total= 41\% \\
\hline
\end{tabular}

Table 4 shows that Factor 1 (Touch and Wireless devices) explains $24 \%$ of the variance, and the subcategories of the instrument Tablet/Ipad (Frec.TIC.P10.7), Digital board (Frec.TIC.P10.8), Smartwatch (Frec.TIC.P10.10), and Clickers (Frec.TIC.P10.12) are part of this factor. Factor 2 (Storage, display and sound devices) includes the sub-categories of the scale Video projector (Frec.TIC.P10.3), USB memory (Frec.TIC.P10.15), and Speakers (Frec.TIC.P10.16), and it explains 17\% of the variance. In total, the percentage of variance explained by the two factors is $41 \%$. As mentioned above, the sub-categories Desktop PC (Frec.TIC.P10.1), Laptop (Frec.TIC.P10.2), Smartphone (Frec.TIC.P10.9), Computer room (Frec.TIC.P10.11), Photographic and video camera (Frec.TIC.P10.13), and Laser pointer for presentations.TIC.P10.14) showed very low correlations between them and the others. For this reason, they do not appear in this factorial structure. These results correspond to those found through polychoric matrixes (see Figure 1).

\section{Factorial structure for the set of Software sub-categories}

It was found that the 17 sub-categories of the Software category can be grouped into the three factors shown in Table 5.

Table 5 shows that Factor 1(Tools for creating educational materials) explains 24\% of the variance, and the sub-categories of the instrument: Tools for creating and editing videos (Frec.TIC.P10.20), Tools for editing images (Frec.TIC.P10.22), Tools for creating digital material such as stories, comics, books or magazines (Frec.TIC.P10.23), Tools for creating computer graphics (Frec.TIC.P10.25), App to boost activities/exercises with Gamification (Frec.TIC.P10.27), App to boost activities/exercises with Robotics (Frec.TIC.P10.28), and App to boost activities/exercises with Augmented Reality (Frec.TIC.P10.29) are part of this factor. Factor 2 (Tools for interaction, messaging and network storage) includes the sub-categories of the scale, Internet browser (Frec.TIC.P10.4), E-mail (Frec.TIC.P10.5), Instant messaging/chat (Frec.TIC.P10.6), Tools for organizing the agenda (Frec.TIC.P10.18), and Tools for sharing, managing and creating information (Frec.TIC.P10.21), and explains $14 \%$ of the variance. Factor 3 (Tools for organization, presentation and collaborative work) explains $13 \%$ of variance and includes the sub-categories Discussion forums (Frec.TIC.P10.17), Tools for creating interactive presentations (Frec.TIC.P10.19), Tools for creating mind/ideas maps (Frec.TIC.P10.24), and Tools for boosting videoconferences (Frec.TIC.P10.26). In total, the percentage of variance explained by the three factors is $51 \%$. As mentioned above, the sub-category Tool for detecting plagiarism (Frec.TIC.P10.30) shows a very low correlation with the others. For this reason, 
Ricardo-Barreto, Jabba Molinares, Llinás, Peña Santodomingo, Astorga Acevedo, Acevedo Rodríguez, Baloco Navarro, \& Villarreal Villa

it does not appear in this factorial model. These results correspond to those found through polychoric matrixes (see Figure 2).

Table 5. Factorial analysis of Software sub-categories

\begin{tabular}{|c|c|c|c|c|c|}
\hline Factors & Sub-categories & Factor 1 & Factor 2 & Factor 3 & Communalities \\
\hline \multirow{7}{*}{$\begin{array}{c}\text { Factor } 1 \text { - Tools for creating } \\
\text { educational materials }\end{array}$} & Frec.TIC.P10.20 & 0,61 & 0,04 & 0,33 & 0,481 \\
\hline & Frec.TIC.P10.22 & 0,70 & 0,03 & 0,21 & 0,533 \\
\hline & Frec.TIC.P10.23 & 0,85 & $-0,06$ & 0,23 & 0,787 \\
\hline & Frec.TIC.P10.25 & 0,76 & $-0,10$ & 0,27 & 0,661 \\
\hline & Frec.TIC.P10.27 & 0,83 & $-0,05$ & $-0,02$ & 0,689 \\
\hline & Frec.TIC.P10.28 & 0,78 & $-0,06$ & 0,04 & 0,61 \\
\hline & Frec.TIC.P10.29 & 0,59 & $-0,11$ & 0,00 & 0,359 \\
\hline \multirow{5}{*}{$\begin{array}{l}\text { Factor } 2 \text { - Tools for interac- } \\
\text { tion, messaging and network } \\
\text { storage }\end{array}$} & Frec.TIC.P10.4 & $-0,08$ & 0,80 & 0,09 & 0,656 \\
\hline & Frec.TIC.P10.5 & $-0,16$ & 0,68 & 0,02 & 0,482 \\
\hline & Frec.TIC.P10.6 & $-0,16$ & 0,68 & 0,19 & 0,526 \\
\hline & Frec.TIC.P10.18 & $-0,07$ & 0,49 & 0,39 & 0,391 \\
\hline & Frec.TIC.P10.21 & 0,22 & 0,60 & 0,32 & 0,516 \\
\hline \multirow{4}{*}{$\begin{array}{c}\text { Factor } 3 \text { - Tools for organi- } \\
\text { zation, presentation and col- } \\
\text { laborative work }\end{array}$} & Frec.TIC.P10.17 & $-0,06$ & 0,32 & 0,62 & 0,493 \\
\hline & Frec.TIC.P10.19 & 0,15 & 0,24 & 0,53 & 0,362 \\
\hline & Frec.TIC.P10.24 & 0,36 & $-0,09$ & 0,77 & 0,727 \\
\hline & Frec.TIC.P10.26 & 0,17 & 0,16 & 0,61 & 0,432 \\
\hline \multicolumn{2}{|c|}{ Percentage of Variance explained } & $24 \%$ & $14 \%$ & $13 \%$ & Total $=51 \%$ \\
\hline
\end{tabular}

\section{Factorial structure for the set of DER sub-categories}

For the seven sub-categories considered in the DER category, a final 2-factor factorial model was found, as indicated in Table 6.

Table 6. Factorial analysis of DER sub-categories

\begin{tabular}{|c|l|c|c|c|}
\hline Factors & \multicolumn{1}{|c|}{ Sub-categories } & Factor 1 & Factor 2 & Communalities \\
\hline \multirow{4}{*}{ Factor 1 - Digital repositories } & Frec.RED.P11.6 & 0,49 & 0,35 & 0,43 \\
\cline { 2 - 5 } & Frec.RED.P11.7 & 0,94 & 0,04 & 0,89 \\
\cline { 2 - 5 } & Frec.RED.P11.8 & 0,79 & $-0,11$ & 0,60 \\
\hline \multirow{3}{*}{$\begin{array}{c}\text { Factor 2- Multimedia re- } \\
\text { sources, Wiki and LMS }\end{array}$} & Frec.RED.P11.1 & $-0,27$ & 0,68 & 0,46 \\
\cline { 2 - 5 } & Frec.RED.P11.2 & 0,11 & 0,67 & 0,49 \\
\cline { 2 - 5 } & Frec.RED.P11.3 & 0,19 & 0,58 & 0,42 \\
\cline { 2 - 5 } & Frec.RED.P11.4 & 0,34 & 0,37 & 0,30 \\
\hline \multicolumn{2}{|c|}{ Percentage of Variance explained } & $\mathbf{2 9} \%$ & $\mathbf{2 2} \%$ & Total= 51\% \\
\hline
\end{tabular}


Trends in Using ICT Resources by Professors in HEIs

\section{RELIABILITY ANALYSIS}

Internal consistency was analyzed using Cronbach's Alpha $(\alpha)$ and Mc Donald's Omega $(\omega)$. The results are summarized in Table 7.

Table 7. Validation of the instrument categories by Cronbach's Alpha $(\alpha)$ and Mc Donald's Omega $(\omega)$.

\begin{tabular}{|c|c|c|c|c|c|c|}
\hline Categories & Factors & Sub-categories & $\alpha$ & $\omega$ & $\begin{array}{c}\text { global } \\
\alpha\end{array}$ & $\begin{array}{c}\text { global } \\
\omega\end{array}$ \\
\hline \multirow[t]{2}{*}{ Hardware } & $\begin{array}{c}\text { Touch and Wireless } \\
\text { devices }\end{array}$ & \begin{tabular}{|l} 
Frec.TIC.P10.7, \\
Frec.TIC.P10.8, \\
Frec.TIC.P10.10, \\
Frec.TIC.P10.12
\end{tabular} & 0.72 & 0.73 & \multirow[t]{2}{*}{0.61} & \multirow[t]{2}{*}{0.62} \\
\hline & $\begin{array}{l}\text { Storage, display and } \\
\text { sound devices }\end{array}$ & $\begin{array}{l}\text { Frec.TIC.P10.3, } \\
\text { Frec.TIC.P10.15, } \\
\text { Frec.TIC.P10.16 }\end{array}$ & 0.62 & 0.62 & & \\
\hline \multirow{3}{*}{ Software } & $\begin{array}{l}\text { Tools for creating ed- } \\
\text { ucational materials }\end{array}$ & $\begin{array}{l}\text { Frec.TIC.P10.20, } \\
\text { Frec.TIC.P10.22, } \\
\text { Frec.TIC.P10.23, } \\
\text { Frec.TIC.P10.25, } \\
\text { Frec.TIC.P10.27, } \\
\text { Frec.TIC.P10.28, } \\
\text { Frec.TIC.P10.29 }\end{array}$ & 0.80 & 0.82 & \multirow{3}{*}{0.80} & \multirow{3}{*}{0.82} \\
\hline & $\begin{array}{l}\text { Tools for interaction, } \\
\text { messaging and net- } \\
\text { work storage }\end{array}$ & $\begin{array}{l}\text { Frec.TIC.P10.4, } \\
\text { Frec.TIC.P10.5, } \\
\text { Frec.TIC.P10.6, } \\
\text { Frec.TIC.P10.18, } \\
\text { Frec.TIC.P10.21 }\end{array}$ & 0.81 & 0.81 & & \\
\hline & $\begin{array}{l}\text { Tools for organiza- } \\
\text { tion, presentation and } \\
\text { collaborative work }\end{array}$ & \begin{tabular}{|l} 
Frec.TIC.P10.17, \\
Frec.TIC.P10.19, \\
Frec.TIC.P10.24, \\
Frec.TIC.P10.26
\end{tabular} & 0.75 & 0.76 & & \\
\hline \multirow[b]{2}{*}{ DER } & Digital repositories & $\begin{array}{l}\text { Frec.RED.P11.6, } \\
\text { Frec.RED.P11.7, } \\
\text { Frec.RED.P11.8 }\end{array}$ & 0.79 & 0.81 & \multirow[b]{2}{*}{0.74} & \multirow[b]{2}{*}{0.75} \\
\hline & $\begin{array}{c}\text { Multimedia resources, } \\
\text { Wiki and LMS }\end{array}$ & $\begin{array}{l}\text { Frec.RED.P11.1, } \\
\text { Frec.RED.P11.2, } \\
\text { Frec.RED.P11.3, } \\
\text { Frec.RED.P11.4 }\end{array}$ & 0.68 & 0.68 & & \\
\hline
\end{tabular}

It was found that globally Cronbach's Alpha $(\alpha)$ and Mc Donald's Omega $(\omega)$ have values greater than 0.6 , highlighting the indices corresponding to the Software category, where these values are greater than 0.80 . The consistency indices for the subscales (factors) also have similar behavior. In general, the values found are within the range allowed by the scientific community (to be greater than 0.6). 


\section{DISCUSSION}

The fundamental findings of this study focused on showing the trends of ICT use by professors, including relevant elements within the framework of these trends due to their relevance in the pedagogical implications of ICT use in university education scenarios.

From this perspective, in the hardware category there is a trend to greater use of a laptop $(86.6 \%)$ and desktop PC $(76.29 \%)$, which is consistent with similar findings in other studies such as those by Bautista et al. (2013), Kay and Lauricella (2016), Loague et al. (2018), and Sáez-López et al. (2019). This preference of professors makes evident how, amidst the accelerated pace of technological development characterized by innovative mobile options, the desktop PC continues holding an important place in the professors' working environment (Noriega et al., 2014). This is significant because it reveals that the disappearance of desktop computers would not be a process as fast as anticipated by other trend analyses that predicted their early replacement (Ward, 2011).

In this regard, the findings of this study indicate that desktop computers still maintain a significant percentage of use in professor trends. The explanation for this trend could be found analyzing the specific features of the university context in our regions, still characterized by scenarios where computers remain important compared to mobile devices (Adell \& Castañeda, 2012). On the other hand, this trend could also be understood from the findings of similar studies with student population (Robles et al., 2012; Sáez-López et al., 2019) that showed that students did not use their mobile devices so often to review activities and other academic resources, but preferred to use their computers.

The trend in mention coincides with the percentage of use by mobile devices such as Smartphones (76.29\%), a relevant position presented in Crompton and Burke (2018). They emphasize the use of mobile devices to complement learning processes beyond the classroom. However, the high frequency of use of smartphones by professors $(76.29 \%)$ may or may not be focused on the educational environment because the use of apps (gamification, robotics, augmented reality) to boost classroom activities has a low grade of acceptance.

The previous findings in this first category raise the need for broader analyses that include other elements present in the dynamics of the educational processes mediated by the ICT use. Among these elements could be contemplated the interaction styles that, as Abascal and Moriyon (2002) point out, correspond to certain paradigms of human-computer and multimedia interaction. Here can be found aspects related to virtual reality, ubiquitous computing and augmented reality, which allow us to understand the low acceptance that professors still have regarding the use of certain apps to boost activities (gamification, robotics, augmented reality) such as the usability linked to productivity and user satisfaction. For this reason, the age of the professors and the years of performance of their work are important factors to be included in this discussion, since the professor role involves reinventing his or her teaching practice to adapt to new forms of pedagogical interactions mediated by ICT. In this study, the age group in which most of the participants were located is between 30 and 50 years of age $(75 \%)$, and they have been teaching at university level largely between 6 to 10 years $(27 \%)$ and from 16 to 20 years $(18 \%)$. According to these data, we are facing a population that has experienced the dizzying technology transition. Most of them surely used the old mechanical typewriter devices, saw the arrival of the first, huge, and heavy computers, and had barely managed to learn the word processors basics, when quickly they faced the arrival of the first cellular phones and internet in Colombia (J. E. Padilla et al., 2014; Rodríguez et al., 2014). All this helps to understand aspects of the trends of use of ICT revealed by the findings in the participating professors, whose process of adapting to the new ways of assuming their pedagogical role has involved a whole itinerary of fascinating and challenging metamorphosis.

In this context of transformation and challenges, professors demonstrate a process of gradually appropriating the new tools that can support their teaching work, and, in this sense, the findings show that the basic elements to prepare presentations using a computer (Laptop, Desktop computer, Video 
projector, speakers, USB memory) are the most frequently used (Table 4). This result is in line with the study carried out by Carvajal et al. (2018) in which the frequent use of the video projector for the visualization of materials is evidenced. This is understood from the facility and multiple possibilities that offer the elaboration of presentations through a computer, which today replace the classic posters previously used by professors to present to their classes and that required certain psychomotor skills in their elaboration (Adell \& Castañeda, 2012).

On the other hand, results show that some resources that require a greater infrastructure and/or additional investment, such as Clickers, digital board, and laser pointer, are less frequent elements. This low trend in the use of these resources would be linked to issues of investment in technological infrastructure to support teaching in the HEI in which the professors participating in the study work (Barroso-Osuna et al., 2019; Marcelo et al., 2016). This poses a challenge because it involves issues of managerial willingness to make decisions about the investment in these resources, which would also be permeated by the perception of cost-benefit of using these new tools. According to Salinas (2004), without the existence of clear strategic lines regarding the infrastructure, there is little that can be done on ICT-based teaching. Therefore, it is important that HEIs have a technological plan for the successful implementation of these changes that require an adequate infrastructure. However, this approach differs somewhat from other authors such as Vázquez-Cano and Sevillano-García (2015) have pointed out. In their work on the smartphone in higher education, they highlight the emergence of what is called ubiquitous learning as a new paradigm that is emerging and where the physical space is not a determinant variable in the process because the new smartphones allow other forms of interaction to learn from anywhere and from a global perspective that does not require a localized technological infrastructure.

Nevertheless, this would be the object of a broader discussion since the issue of the existence of adequate technological infrastructure is not limited only to the presence of a series of equipment located on the physical plant of educational institutions (computer rooms, digital boards, videoconference rooms), but also to a whole process of adaptation of the new digital scenarios where the new learning interactions take place, which implies curricular adjustments, technical support, and didactic accompaniment for the design of new virtual environments, permanent training of professors participating in the process, collaborative and networked work, among other aspects that become part of this new educational reality mediated by ICT.

Under this same perspective, in the software category, there is a trend towards a more frequent use of interaction, messaging, and storage tools (e-mail, internet browser, instant messaging/chat, tools for sharing, managing and creating information) (Table 5, Factor 2). This places us in a communicative context that goes beyond the instrumental use of messaging tools. In this regard, Sánchez-García et al. (2015) highlight the democratization and expansion role of the Internet that requires the development of new competencies, but which also implies continuing to develop reading comprehension. In the face of this, we could add the necessary attention to other aspects of this same communicative process, among them the ethical and attitudinal ones. As stated by Engen (2019), the use of ICT, in the beginning, has to do with instrumental skills; the second aspect is much more complex and must include pedagogical, ethical, and attitudinal dimensions.

In this regards, the findings call attention to the low trend of use of tools for detecting plagiarism (Frec.TIC.P10.230) (Table 2 and Figure 2), which raises new questions about the factors associated with this low trend of use of tools relating to the ethical care of the intellectual property of what the students consult and what they share in their communications and works. This is worrying as there is evidence that the level of plagiarism in students is related to the level of Internet knowledge: the higher the level of plagiarism, the higher the level of Internet knowledge (Torres et al., 2018). However, this low trend of use of tools for detecting plagiarism by professors may not be associated with a lack of concern in this very delicate issue in educational terms; it probably may be explained by the gradual process professors are going through to get to know and appropriate the effective use of the 
tools offered by ICT to address these ethical issues, while students generally have a greater mastery and knowledge of the Internet.

Another important aspect is one found in the DER category: the greater use that professors make of video as an online educational resource (Table 3). This shows a preference for the audiovisual format that can also be found in different online platforms, which is consistent with other studies' findings that confirm the need to exploit the resources available on the Internet to promote learning from different kind of devices (Astorga et al., 2017; Sáez-López et al., 2019). On the contrary, results show little use of Wiki and Digital walls that have the possibility of free and online access but are interactive resources that enable the social construction of knowledge (Table 3). The above raises the concern for collaborative work in networks and the use of multiple tools available online to favor interaction by using the potential offered by ICTs. It again reveals that the availability of multiple tools offered is not enough; it also requires a process of professor training in the use of new technological alternatives to support his/her pedagogical work (Iriarte et al., 2015), which includes the creation and editing of educational materials (tools for the creation of computer graphics, images, and videos) that was another of the sub-categories with less frequent use. Nevertheless, findings also show the interest of participating professors to be open to try to make incursions into those processes of creation of digital materials. This is made evident when they show their preference to use videos and images banks, essential resources for the construction of educational materials. In this regards, similar studies on ICTs in higher education (Al-Azawei, 2019; Iriarte et al., 2017) have shown experiences on the creation of different educational materials with these digital resources.

In relation to emergent technologies, among the participating professors there is a low trend of use of apps to boost activities with Gamification. This result coincides with the findings of Almeida and Simoes (2019) who, by an analysis of projects of didactic innovation in higher education, identify a low acceptation of the so-called "serious games" and of gamification practices; besides, they recognize that the use of these tools requires a change of roles, attitudes, and beliefs by both professors and students. In a similar way, among the less used tools, it is also found the apps to boost activities with Augmented Reality, which, according to Barroso-Osuna et al. (2019), is related to the difficulties identified for implementing Augmented Reality in the university context such as lack of experience with this technology, conceptual foundations, and support by the institution for the appropriation of new technologies.

Another element that stands out in the findings is that of social networks, which professors identify with less or very little use, even though many researches recognize the benefit of using them in the development of the teaching practice (Abella-García et al., 2019; Astorga et al., 2017; Manca \& Ranieri, 2017). This low frequency of use pointed out by professors could be related to age factor, since of the total of respondent more than $50 \%$ are older than 41 years, and according to the study carried out by M. T. Padilla et al. (2016) adults over 40 tend to use this type of network less in comparison with the younger population. However, this may differ in the case of the professors participating in this study, where a strong correlation with the other sub-categories of digital educational resources is not observed (Figure 3), so it could be more related to an unfavorable perception of the pedagogical use that professors consider social networks may have, an issue linked to the image built around the specific use of these interaction scenarios.

Regarding this, in the Colombian regional context where this research is located, social networks have been generally used for informal and personal interaction with the circle of friends of their users and have also been scenarios where issues of regional socio-political polarization are frequently reflected, with the circulation of unverified contents or fake news, as confirmed by a study from the University of Oxford that makes an inventory of the organized manipulation by social networks in 2019 at a global level, placing Colombia among the countries that spread political disinformation by social network (Bradshaw \& Howard, 2019). This fact, as is understandable, generates a certain skepticism in professors of HEI to consider social networks as an academic scenario or a source of reliable and rigorous information for educational purposes, a perception related to the opportunity doors opened 
by Internet that democratizes the production of contents, but at the same time constitutes a risk with the type of content produced and the responsibility that this entails, as stated in the Sánchez-García studies (2015), by having available the tools and spaces to publish our own information, we are all potential producers of content and are no longer simple consumers of information.

Then the challenge is to discover and take advantage of the pedagogical potential that this makes possible. This is where the pedagogical reflection takes on greater meaning and relevance to transcend the dangers of a techno centrism that converts technology into the main axis of education.

\section{CONCLUSION}

This study has proposed to know the tendencies of use of ICT by the teachers of the universities in the context of Antioquia region, from the categories of hardware, software, and digital educational resources, as a strategy that makes it possible to understand and describe the preferences with respect to the use of the digital technologies addressed. All this with the purpose of generating reflections, analysis, and inferences regarding the studied reality. As well as, to glimpse and favor in the future the integral understanding of the digital competence of professors.

\section{IMPLICATIONS OF THE STUDY}

In this context, the trends of use of ICT that were evidenced by the study place a greater preference of professors for storage, display, and sound devices (USB memory, video projector, speakers), and where the computer, both desktop and laptop, remains a basic tool for their teaching, now enriched by tools for interaction, messaging, and network storage. In the same way, the use of smartphones was highlighted, which does not show any relationship with their pedagogical or academic use. The analysis of this first group of trends allowed concluding that ICT, in the context of higher education, has become a natural part of the formative dynamics of university life and therefore it allows tracking skills and competences in terms of activities and specific uses that will help to discover innovative ways to develop the educational work.

Within these trends, those that showed a low level of use were also relevant; among them are tools for detecting plagiarism, social networks as a pedagogical resource, and apps to boost activities or exercises (gamification, robotics, augmented reality). The analysis of this low trend of use and its related factors allowed us to conclude that, although professors have managed to adapt quickly to the new dynamic mediated by ICT, the accelerated pace of technological advances and developments that are appearing overwhelms them. This poses a series of challenges not only for professors but also for HEI and the state entities that regulate education in the region and the country.

Based on the trends of ICT use, opportunities can be suggested for HEI to ongoing professor training by taking actions and targeting issues such as the following:

- The training of professors in emerging digital technologies and tools and their potential pedagogical use in the educational context. In this sense, the need to strengthen the didactic use of technologies with new approaches is highlighted, based on constant updates according to the described trends of use and the levels of competences of higher education professors.

- Adequate technological infrastructure in the HEI, which not only refers to issues of localized physical infrastructure, but also to other elements necessary for the operation of digital scenarios, which involve elements such as curriculum design, didactic accompaniment for the new interaction dynamics in virtual environments, networking, technical support, and other important aspects in this ICTmediated reality. Therefore, it is recommended that HEI provide professors with the technological resources and connectivity relevant to educational innovation, and facilitate the use of the various ICT tools (hardware, software, DER) in the development of their professional practice, taking advantage of all the pedagogical potential they offer. 
- An interdisciplinary and collaborative work that promotes new technological developments relevant to the pedagogical work, which strengthens the educational mission developed by the HEI. Here the studies of trends that analyze the relationships with other factors associated to the preference of use in concrete contexts and in specific regional scenarios, which also consider the cultural elements that give it meaning, take on importance.

- A broad framework for reflection on ICT in higher education, involving pedagogical, ethical, and attitudinal dimensions and, in general, innovative pedagogical approaches (focused on the collaborative, authentic, project-based learning) could be the most appropriate to develop important components of digital competence such as critical awareness and capacity for evaluation of data, information and digital content, problem solving and creativity (Kluzer \& Pujol Priego, 2018).

\section{FUTURE STUDIES}

From this study it is possible to glimpse other paths and research lines that establish bases for the development of future proposals that explore the realities of professors in other regional contexts to carry out comparative studies that make possible to contrast results and a greater understanding of this topic. On the other hand, from the methodological point of view, the relevance of carrying out mixed studies that provide a greater level of understanding of the associated factors and of the complex context where the interaction of the participating population takes place is highlighted.

\section{LIMITATIONS OF THE STUDY}

Within the limitations of this study, consideration would be given to evaluating the extent of questionnaires covering categories needed to be addressed in detail because of the relevance of their component. In this sense, for subsequent studies that had the objective of broadening or deepening these categories, the instrument could be enriched by including other relevant questions that were identified in the analysis. However, in such a case, it is suggested to segment the instrument into separate sessions and at different times. This would facilitate its application and not generate fatigue in the study participants because of the extension of the instrument. Without a doubt, the topic of ICT and its multiple applications in the educational scenario, in its different levels and contexts, opens up a panorama of possibilities to continue researching and generating new developments that favor the educational quality of present and future institutions.

\section{REFERENCES}

Abascal, J., \& Moriyón, R. (2002). Tendencias en interacción persona computador. Inteligencia artificial [Trends in human-computer interaction. Artificial intelligence]. Revista Iberoamericana de Inteligencia Artificial, 6(16), 924. https://www.redalyc.org/pdf/925/92561602.pdf

Abella-García, V., Delgado-Benito, V., Ausín-Villaverde, V., \& Hortigüela-Alcalá, D. (2019). To tweet or not to tweet: Student perceptions of the use of Twitter on an undergraduate degree course. Innovations in Education and Teaching International, 56(4), 402-411. https://doi.org/10.1080/14703297.2018.144450 3

Adell, J., \& Castañeda, L. (2012). Tecnologías emergentes, ¿pedagogías emergentes? [Emerging technologies, emerging pedagogies?]. In J. Hernández, M. Pennesi, D. Sobrino \& A. Vázquez (Eds.), Tendencias emergentes en educación con TIC, (pp. 13-32). Asociación Espiral, Educación \& Tecnología. http://hdl.handle.net/10201/29916

Al-Azawei, A. (2019). What drives successful social media in education and e-learning? A comparative study on Facebook and Moodle. Journal of Information Technology Education: Research, 18, 253-274. https://doi.org/10.28945/4360

Al-Emran, M., Elsherif, H. M., \& Shaalan, K. (2016). Investigating attitudes towards the use of mobile learning in higher education. Computers in Human behavior, 56, 93-102. https://doi.org/10.1016/j.chb.2015.11.033

Almeida, F., \& Simoes, J. (2019). The role of serious games, gamification and industry 4.0 tools in the education 4.0 paradigm. Contemporary Educational Technology, 10(2), 120-136. https://doi.org/10.30935/cet.554469 
Trends in Using ICT Resources by Professors in HEIs

Alshwaier, A., Youssef, A., \& Emam, A. (2012). A new trend for e-learning in KSA using educational clouds. Advanced Computing, 3(1), 81. https://pdfs.semanticscholar.org/ef06/45690098003dd0dd2bcb45c8597c1dc808c5.pdf

Alvarado, M., Zermeño, M. G. G., \& Mejía, I. A. G. (2013). Uso de elementos multimedia en el nivel medio superior [Use of multimedia elements in the upper middle level]. Revista educación \& tecnología, (4), 13-29. https://dialnet.unirioja.es/descarga/articulo/5072154.pdf

Amhag, L., Hellström, L., \& Stigmar, M. (2019). Teacher educators' use of digital tools and needs for digital competence in higher education. Journal of Digital Learning in Teacher Education, 35(4), 203-220. https://doi.org/10.1080/21532974.2019.1646169

Anaya, Y., Díaz, S., \& Martínez, J. (2012). El uso de las TIC como herramienta para el aprendizaje significativo del inglés [The use of ICT as a tool for meaningful English learning]. Rastros Rostros, 14(27). https://revistas.ucc.edu.co/index.php/ra/article/view/490

Astorga, C. \& Ricardo, C. (2014). Diseño de un programa de formación docente frente al uso pedagógico de los recursos educativos digitales \& tecnológicos, para el fortalecimiento de las competencias TIC [Design of a teacher training program on the pedagogical use of digital \& technological educational resources to strengthen ICT skills]. [Unpublished manuscript]. Universidad del Norte, Colombia.

Astorga, C., Rodríguez, C., Saad, S., Ricardo, I., Ricardo, C. \& Borjas, M. (2017). Orientaciones pedagógicas para enriquecer las prácticas ludoevaluativas desde TIC en contextos universitarios [Pedagogical guidelines to enrich ludo-evaluation practices from ICT in university contexts]. Revista Virtual Universidad Católica del Norte, 52, 57-76. http://revistavirtual.ucn.edu.co/index.php/RevistaUCN/article/view/944

Avalos, B. (2011). Teacher professional development in teaching and teacher education over ten years. Teaching and Teacher Education, 27(1), 10-20. https://doi.org/10.1016/i.tate.2010.08.007

Aydin, C., Woge, M. G., \& Verbeek, P. (2019). Technological environmentality: Conceptualizing technology as a mediating milieu. Philosophy \& Technology, 32(2), 321-338. https://doi.org/10.1007/s13347-018-0309-3

Barroso-Osuna, J., Gutiérrez-Castillo, J. J., Llorente-Cejudo, M. d. C., \& Valencia Ortiz, R. (2019). Difficulties in the incorporation of augmented reality in university education: Visions from the experts. Journal of New Approaches in Educational Research, 8(2), 126-141. https://doi.org/10.7821/naer.2019.7.409

Bautista, G., Escofet, A., Forés, A., López, M., \& Marimon, M. (2013). Superando el concepto de nativo digital. Análisis de las prácticas digitales del estudiantado universitario [Going beyond the concept of the digital native. Analysis of the digital practices of university students]. Digital Education Review, 24(1), 1-22. http://hdl.handle.net/2445/58966

Becker, S. A., Cummins, M., Davis, A., Freeman, A., Glesinger Hall, C., \& Ananthanarayanan, V. (2017). NMC Horizon Report: 2017 Higher Education Edition. https://www.learntechlib.org/p/174879/

Bentler, P. M., \& Chou, C. P. (1987). Practical issues in structural modeling. Sociological Methods Research, 16, 78117. https://doi.org/10.1177/0049124187016001004

Berenguer, D. P., \& Molina, J. G. (2016). Un enfoque para la creación de contenido online interactivo [An approach to creating interactive online content]. Revista de Educación a Distancia, (51). https://doi.org $/ 10.6018 / \mathrm{red} / 51 / 3$

Bishop, J. (2008). Book review: Raykov, T., \& Marcoulides, G. A. (2006). A first course in structural equation modeling (2nd ed.). Mahwah, NJ: Lawrence Erlbaum. Organizational Research Methods, 11, 408-411. https://doi.org/10.1177/1094428107308985

Bradshaw, S., \& Howard, P. (2019). The global disinformation disorder: 2019 global inventory of organised social media manipulation. Working Paper 2019.2. Project on Computational Propaganda. https://comprop.oii.ox.ac.uk/wp-content/uploads/sites/93/2019/09/CyberTroop-Report19.pdf

Bryer, J., \& Speerschneider, K. (2016). Package'Likert': Analysis and visualization Likert items. In R package version, 1.3. 5. https://cran.r-project.org/web/packages/likert/likert.pdf

Burke, L. A., James, K., \& Ahmadi, M. (2009). Effectiveness of PowerPoint-based lectures across different business disciplines: An investigation and implications. Journal of Education for Business, 84(4), 246-251. https://doi.org/10.3200/JOEB.84.4.246-251 
Cabero, J. (2014). Formación del profesorado universitario en TIC. Aplicación del método Delphi para la selección de los contenidos formativos [Training of university teachers in ICT. Application of the Delphi method for the selection of training content]. Educación XX1, 17(1), 111-132. http://revistas.uned.es/index.php/educacionXX1/article/view/10707

Camacho-Miñano, M., \& Del Campo, C. (2016). Useful interactive teaching tool for learning: clickers in higher education. Interactive Learning Environments, 24(4), 706-723. https://doi.org/10.1080/10494820.2014.917108

Campo-Arias, A., \& Oviedo, H. C. (2008). Propiedades psicométricas de una escala: la Consistencia interna [Psychometric properties of a scale: Internal consistency]. Revista de Salud Pública, 10(5), 831-839. https://www.scielosp.org/article/rsap/2008.v10n5/831-839/

Carpenter, J., Rosenberg, J., Dousay, T., Romero-Hall, E., Trust, T., Kessler, A., Phillips, M., Morrison, S., Fischer, C., \& Krutka, D. (2019). What do teacher educators think of teacher education technology competencies? In K. Graziano (Ed.), Proceedings of Society for Information Technology \& Teacher Education International Conference (pp. 796-801). Las Vegas, NV, United States: Association for the Advancement of Computing in Education (AACE). https://www.learntechlib.org/primary/p/207735/

Carvajal, J., Suárez, F., \& Quiñónez, X. (2018). Las TIC en la educación universitaria [ICT in university education]. Universidad Ciencia \& Tecnología, 22(89). http://uctunexpo.autanabooks.com/index.php/uct/article/view/28

Castells, M. (2005). La dimensión cultural de Internet [The cultural dimension of the Internet]. https://www.uoc.edu/culturaxxi/esp/articles/castells0502/castells0502.html

Cobo, C. (2011). El concepto de tecnologías de la información. Benchmarking sobre las definiciones de las TIC en la sociedad del conocimiento [The concept of information technology. Benchmarking on the definitions of ICTs in the knowledge society]. ZER: Revista de Estudios de Comunicación= Komunikazio Ikasketen Aldizkaria, 14(27), 295-318. https://www.ehu.eus/ojs/index.php/Zer/article/view/2636/2182

Coll, C. (2013). La educación formal en la nueva ecología del aprendizaje: tendencias, retos \& agenda de investigación [Formal education in the new learning ecology: Trends, challenges \& research agenda]. In J. L. Rodríguez Illera (Ed.), Aprendiraje \& educación en la sociedad digital, (pp.156-170). Universitat de Barcelona. https://doi.org/10.1344/106.000002060

Cortina, J. (1993). What is coefficient alpha? An examination of theory and applications. Journal of Applied Psychology, 78, 98-104. https://doi.org/10.1037/0021-9010.78.1.98

Costello, A. B., \& Osborne, J. W. (2005). Best practices in exploratory factor analysis: Four recommendations for getting the most from your analysis. Practical Assessment. Research and Evaluation, 10, 1-9. https://doi.org/10.7275/jyj1-4868

Crompton, H., \& Burke, D. (2018). The use of mobile learning in higher education: A systematic review. Computers \& Education, 123, 53-64. https://doi.org/10.1016/j.compedu.2018.04.007

Dabbagh, N., Fake, H., \& Zhang, Z. (2019). Perspectivas de los estudiantes sobre el uso de la tecnología para el aprendizaje en la educación superior [Student perspectives of technology use for learning in higher education]. RIED. Revista Iberoamericana de Educación a Distancia, 22(1), 127-152. https://doi.org/10.5944/ried.22.1.22102

Dominguez, S. A. (2014). ¿Matrices policóricas/tetracóricas o matrices Pearson? Un estudio metodológico [Polycoric/tetracoric matrices or Pearson matrices? A methodological study]. Revista Argentina de Ciencias del Comportamiento, 6(1). http://repositorio.uigv.edu.pe/handle/20.500.11818/4414

Dorfsmani, M. (2015). La profesión docente en contextos de cambio: el docente global en la sociedad de la información [The teaching profession in contexts of change: The global teacher in the information society]. Revista De Educación a Distancia, (6DU). https://revistas.um.es/red/article/view/245231

Dută, N., \& Martínez-Rivera, O. (2015). Between theory and practice: The importance of ICT in higher education as a tool for collaborative learning. Procedia-Social and Behavioral Sciences, 180, 1466-1473. https://core.ac.uk/download/pdf/82553097.pdf 
Trends in Using ICT Resources by Professors in HEIs

Engen, B. K. (2019). Comprendiendo los aspectos culturales \& sociales de las competencias digitales docentes [Understanding the cultural \& social aspects of digital teaching skills]. Comunicar: Revista cientifica iberoamericana de comunicación \& educación, (61), 9-19. https://doi.org/10.3916/C61-2019-01

Eshet-Alkalai, Y., \& Soffer, O. (2012). Guest editorial--Navigating in the digital era: Digital literacy: Socio-cultural and educational aspects. Educational Technology \& Society, 15(2), 1. https://go.gale.com/ps/anonymous?id=GALE\%7CA298503762\&sid=googleScholar\&v=2.1\&it=r\&linkaccess $=$ abs\&issn $=14364522 \& \mathrm{p}=\mathrm{AONE} \& \mathrm{sw}=\mathrm{w}$

Falcó, R. F., \& Minguell, M. E. (2016). Las tecnologías como facilitadoras del aprendizaje \& la comunicación en entornos AICLE: la formación permanente del profesorado AICLE en Cataluña [Technologies as facilitators of learning \& communication in AICLE environments: Lifelong learning for AICLE teachers in Catalonia]. In R. Roig-Vila (Ed.), Tecnologia, innovación e investigación en los procesos de enseñanza-aprendizaje (pp. 398408). España: Octaedro.

Ferrari, A., Brečko, B. N., \& Punie, Y. (2014). DIGCOMP: A framework for developing and understanding digital competence in Europe. eLearning Papers (38), 3-17. https://ddd.uab.cat/pub/artpub/2014/174029/indepth a2014n38p18.pdf

Fischer, H., Heise, L., Heinz, M., Moebius, K., \& Koehler, T. (2015). How to identify e-learning trends in academic teaching: Methodological approaches and the analysis of scientific discourses. Interactive Technology and Smart Education, 12(1), 31-43. https://doi.org/10.1108/ITSE-09-2014-0031

Fox, J. (2019). Package "polychor", versión 0.7-10. https://cran.r-project.org/web/packages/polycor/polycor.pdf

Freiberg, A., Stover, J., De la Iglesia, G., \& Fernández, M. (2013). Correlaciones policóricas \& tetracóricas en estudios factoriales exploratorios \& confirmatorios [Polychoric \& tetracoric correlations in exploratory \& confirmatory factorial studies]. Ciencias Psicológicas, 7(2), 151-164. http://www.scielo.edu.uy/scielo.php?script $=$ sci arttext\&pid $=$ S1688-42212013000200005\&lng $=$ es\&tlng $=$ en

Gallego, G. (2019). Modelo para el análisis de aplicaciones visuales educativas en Realidad Aumentada desde la perspectiva de la semiotica visual [Model for the analysis of educational visual applications in Augmented Reality from the perspective of visual semiotics]. [Doctoral dissertation, Universitat Oberta de Catalunya, Barcelona, Spain]. http://hdl.handle.net $/ 10803 / 667112$

Georgina, D. A., \& Hosford, C. C. (2009). Higher education faculty perceptions on technology integration and training. Teaching and Teacher Education, 25(5), 690-696. https://doi.org/10.1016/j.tate.2008.11.004

Grande, M., Cañón, R. \& Cantón, I. (2016). Tecnologías de la información \& la comunicación: Evolución del concepto \& características [Information \& communication technologies: Evolution of the concept \& characteristics]. IJERI: International Journal of Educational Research and Innovation, (6), 218-230. https://www.upo.es/revistas/index.php/IJERI/article/view/1703

Gupta, R. (2011). Faculty perceptions and use of PowerPoint. Language in India, 11(12). http://www.languageinindia.com/dec2011/renuvisualaids.pdf

Hein, K. (2014). Creating and using interactive presentations in distance education courses: A view from the instructor's chair. Theses, Student Research, and Creative Activity: Department of Teaching, Learning and Teacher Education. 43. http://digitalcommons.unl.edu/teachlearnstudent/43

Hernández, R., Fernández, C. \& Batista, P. (2014). Metodología de la Investigación (6th ed.) [Research methodology (6th ed.)]. Mc Gray Hill.

Instituto Nacional de Tecnologías Educativas \& de Formación del Profesorado [INTEF]. (2017). Marco común de competencia digital docente [Common framework for digital educational competence]. https://intef.es/tag/marco-comun-de-competencia-digital-docente/

International Society for Technology in Education [ISTE]. (2009). The ISTE National Education Technology Standards and Performance Indicators for Educators. http://www.iste.org

Iriarte, F., Said, E., Valencia, J., \& Ordóñez, M. (2015). Propuesta de modelo para el fortalecimiento del uso de las TIC en contextos escolares [Proposed model for strengthening the use of ICTs in school settings]. Colombia Digital. https://www.calidadeducativasm.com/wp-content/uploads/2015/10/Propuesta_modelo_fortalecimiento_uso_TIC_en_contextos_escolares.pdf 
Iriarte Díazgranados, F., Ricardo Barreto, C., Ordónez Villa, M., \& Astorga Acevedo. C. (2017). Tecnologías de Información \& Comunicación (TIC) en Educación Superior [Information \& Communication Technologies (ICT) in Higher Education]. In C. Ricardo Barreto \& F. Iriarte Díazgranados (Eds), Las TIC en Educación Superior. Experiencias de Innovación (pp. 15-52). Ediciones Uninorte. http://rd.unir.net/sisi/research/resultados/15119077649789587418552\%20eLas\%20TIC $\% 20$ en $\% 201 \mathrm{la} \% 20$ educacion $\% 20$ superior.pdf

Kay, R., \& Lauricella, S. (2016). Assessing laptop use in higher education: The Laptop Use Scale. Journal of Computing in Higher Education, 28, 18-44. https://doi.org/10.1007/s12528-015-9106-5

Kline, R. B. (2011) Principles and practice of structural equation modeling. Guilford Press.

Kluzer S., \& Pujol Priego, L. (2018). DigComp into Action - Get inspired, make it happen. Publications Office of the European Union. https://doi.org/10.2760/112945

Kruchinin, S. V., Bagrova, E. V., \& Nazarenko, M. A. (2018). Key ways of information technologies for selfeducation development. Pros and cons. 2018 IEEE International Conference "Quality Management, Transport and Information Security, Information Technologies" (IT\&QM\&IS), 663-665.

Lloret-Segura, S., Ferreres-Traver, A., Hernández-Baeza, A., \& Tomas-Marco, I. (2014). El análisis factorial exploratorio de los ítems: una guía práctica, revisada \& actualizada [Exploratory factorial analysis of items: A practical, revised \& updated guide]. Anales de Psicología, 30(3), 1151-1169. https://doi.org/10.6018/analesps.30.3.199361

Loague, A., Caldwell, N., \& Balam, E. (2018). Professors' attitudes and perceptions about technology use in the classroom. Alabama Journal of Educational Leadership, 5, 1-11. https:// eric.ed.gov/?id=EJ1194726

Mahdum, M., Hadriana, H., \& Safriyanti, M. (2019). Exploring teacher perceptions and motivations to ICT use in learning activities in Indonesia. Journal of Information Technology Education: Research, 18, 293-317. https://doi.org/10.28945/4366

Majeed, A., \& Ali, M. (2018). How Internet-of-Things (IoT) making the university campuses smart? QA higher education (QAHE) perspective. In 2018 IEEE 8th Annual Computing and Communication Workshop and Conference (CCWC) (pp. 646-648). IEEE. https://ieeexplore.ieee.org/abstract/document/8301774

Maksimović, J., \& Dimić, N. (2016). Digital technology and teachers' competence for its application in the classroom. Istraživanja u pedagogiji, 6(2), 59-71. https://www.ceeol.com/search/article-detail?id=472983

Manca, S., \& Ranieri, M. (2017). Implications of social network sites for teaching and learning. Where we are and where we want to go. Education and Information Technologies, 22(2), 605-622. https://doi.org/10.1007/s10639-015-9429-x

Mang C. F., \& Wardley L. J. (2019). Tablet use in higher education. In A. Tatnall (Ed), Encyclopedia of education and information technologies. Springer. https://doi.org/10.1007/978-3-319-60013-0 219-1

Marcelo, C., Yot, C. \& Perera, V. H. (2016). El conocimiento tecnológico \& tecnopedagógico en la enseñanza de las ciencias en la universidad. Un estudio descriptivo [Technological \& technopedagogical knowledge in university science teaching. A descriptive study]. Enseñanza de las ciencias. Revista de investigación \& experiencias didácticas, 34(2), 67-86. https:// doi.org/10.5565/rev/ensciencias.1552

McDonald, R. (1999). Test theory: A unified treatment. Lawrence Erlbaum Associates.

Melo, M., Gascó, J., Llopis, J., \& González, R. (2018). Prácticas de los docentes para ampliar las competencias en el uso de las Tecnologías de Información \& Comunicación (TIC) en la educación superior en Colombia [Teacher practices to enhance competencies in the use of information \& communication technologies (ICTs) in higher education in Colombia]. In R. Roig-Vila (Ed.), El compromiso académico \& social a través de la investigación e innovación educativas en la Enseñanza Superior (pp. 294-304). Octaedro.

Ministerio de Educación Nacional [M.E.N.]. (2012). Recursos Educativos Digitales Abiertos: Colombia [Open digital educational resources: Colombia]. Colección Sistema Nacional de Innovación Educativa con uso de TIC. http://aprende.colombiaaprende.edu.co/sites/default/files/naspublic/libroreda 0.pdf

Ministerio de Educación Nacional [M.E.N.]. (2013). Competencias TIC para el Desarrollo Profesional Docente [ICT Competencies for teaching professional development]. https://www.mineducacion.gov.co/1759/articles-339097_archivo pdf competencias tic.pdf 
Trends in Using ICT Resources by Professors in HEIs

Mirete, A. (2016). El profesorado universitario \& las TIC. Análisis de su competencia digital [University teachers \& ICTs. Analysis of your digital competence]. Ensayos: Revista de la Facultad de Educación de Albacete, 31(1), 133-147. https://doi.org/10.18239/ensayos.v31i1.1033

Morffe, A. (2010). Las TIC como herramientas mediadoras del aprendizaje significativo en el pregrado: Una experiencia con aplicaciones telemáticas gratuitas [ICT as a mediating tool for significant learning in undergraduate education: An experience with free telematic applications]. Revista de Artes \& Humanidades UNICA, 20(1), 200-219. https://www.redalyc.org/pdf/1701/170121894009.pdf

Njenga, J. K., \& Fourie, L. C. H. (2010). The myths about e-learning in higher education. British Journal of Educational Technology, 41(2), 199-212. https://doi.org/10.1111/j.1467-8535.2008.00910.x

Noriega, J. Á. V., Moran, L. E. T., \& García, E. E. M. (2014). Evaluación de competencias básicas en tic en docentes de educación superior en México [Evaluation of basic ICT skills in higher education teachers in Mexico]. Píxel-Bit. Revista de Medios \& Educación, (44), 143-155. https://www.redalyc.org/articulo.oa?id $=36829340010$

Organisation for Economic Co-operation and Development [OECD]. (2019a). How's life in the digital age? Opportunities and risks of the digital transformation for people's well-being (Summary in Spanish). OECD Publishing. https://doi.org/10.1787/6b9b7823-es

Organisation for Economic Co-operation and Development [OECD]. (2019b). OECD Skills Outlook 2019: Thriving in a Digital World. OECD Publishing. https://doi.org/10.1787/df80bc12-en

Padilla, J. E., Vega, P. L., \& Rincón, D. A. (2014). Tendencias \& dificultades para el uso de las TIC en educación superior [Trends \& challenges in the use of ICTs in higher education]. Entramado, 10(1), 272-295. http://www.scielo.org.co/pdf/entra/v10n1/v10n1a17.pdf

Padilla, M. T., Suárez, M., \& Sánchez, M. F. (2016). Inclusión digital de los estudiantes adultos que acceden a la universidad: análisis de sus actitudes \& competencias digitales [Digital inclusion of adult learners entering university: analysis of their attitudes \& digital competences]. Revista Complutense de Educación, 27 (3), 12291246. https://doi.org/10.5209/rev RCED.2016.v27.n3.47669

Panadero, E. (2017). A review of self-regulated learning: Six models and four directions for research. Frontiers in psychology, 8(422). https://doi.org/10.3389/fpsyg.2017.00422

Peeraer, J., \& Van Petegem, P. (2011). ICT in teacher education in an emerging developing country: Vietnam's baseline situation at the start of 'The Year of ICT'. Computers \& Education, 56(4), 974-982. https://doi.org/10.1016/j.compedu.2010.11.015

Prendes, M. P. (2011). Innovación con TIC en enseñanza superior: Descripción \& resultados de experiencias en la Universidad de Murcia [Innovation with ICT in higher education: description and results of experiences at the University of Murcia]. Revista electrónica interuniversitaria de formación del profesorado, 14(1), 267-280. http://hdl.handle.net/11162/81401

Prinsloo, T., \& Van Deventer, J. P. (2017). Using the Gartner Hype Cycle to evaluate the adoption of emerging technology trends in higher education -2013 to 2016. In T-C. Huang, R. Lau, Y-M. Huang, M. Spaniol, \& C-H. Yuen (Eds), Emerging technologies for education (pp. 49-57). Springer. https://doi.org/10.1007/978-3$\underline{319-71084-67}$

Qasem, A., \& Viswanathappa, G. (2016). Teacher perceptions towards ICT integration: Professional development through blended learning. Journal of Information Technology Education: Research, 15, 561-575. https://doi.org/10.28945/3562

Ramos, J. P. H. \& Abad, F. M. (2016). La influencia del género a la hora de considerar la Pizarra Digital Interactiva como recurso educativo en la enseñanza universitaria [The influence of gender when considering the Interactive Whiteboard as an educational resource in university education]. Libro de actas (pp. 584-593) EDUNOVATIC 2016-I Congreso Virtual internacional de Educación, Innovación \& TIC. REDINE. Red de Investigación e Innovación Educativa.

Revelle, W. (2018). psych: Procedures for personality and psychological research. Northwestern University. https://www.scholars.northwestern.edu/en/publications/psych-procedures-for-personality-and-psychological-research 
Rodríguez, H., Restrepo, L., \& Aranzazu, D. (2014). Alfabetización informática \& uso de sistemas de gestión del aprendizaje (LMS) en la docencia universitaria [Computer literacy \& use of learning management systems (LMS) in university teaching]. Revista De La Educación Superior, 43(171), 139-159.

https://doi.org/10.1016/j.resu.2015.03.004

Robles, H., Fontalvo, H., \& Guerra, D. (2012). Desarrollo de Habilidades Escriturales Apoyado con Tecnología Móvil [Development of Writing Skills Supported by Mobile Technology]. TESI, 13 (3), 380-402. https://www.researchgate.net/publication/275715024 Desarrollo de habilidades escriturales apoyado con tecnologia movil

Robles, H., Guerrero, J., Llinas, H., \& Montero, P. (2019). Online teacher-students interactions using WhatsApp in a law course. Journal of Information Technology Education: Research, 18, 231-252. https://doi.org/10.28945/4321

Rossing, J. P., Miller, W. M., Cecil, A. K., \& Stamper, S. E. (2012). iLearning: The future of higher education? Student perceptions on learning with mobile tablets. Journal of Scholarship of Teaching and Learning, 12(2), 1 26. https://scholarworks.iu.edu/journals/index.php/josotl/article/view/2023/1985

Sáez-López, J. M., Sevillano-García, M. L., \& Vázquez-Cano, E. (2019). El uso académico del ordenador portátil \& del smartphone en estudiantes universitarios españoles e iberoamericanos [The academic use of the laptop \& smartphone in Spanish and Latin American university students]. EKS, 20, 15.1-15.12. https://doi.org/10.14201/eks2019 20 a15

Salinas, J. (2004). Innovación docente \& uso de las TIC en la enseñanza universitaria [Teaching innovation \& use of ICTs in university education]. RUSC. Universities and Knowledge Society Journal, 1(1),1-16. http://rusc.uoc.edu/rusc/es/index.php/rusc/article/view/v1n1-salinas.htm 1

Sánchez, S. M. (2015). Educación en la nube. Un nuevo reto para los docentes de Educación Media Superior [Education in the cloud. A new challenge for teachers in higher education]. Revista Iberoamericana para la Investigación \& el Desarrollo Educativo, 10, 1-17. http://1-11.ride.org.mx/index.php/RIDESECUNDARIO/article/view/295/288

Sánchez-García, S., Yubero, S., \& Pose, H. (2015). Alfabetización académica \& TIC. Una experiencia de promoción lectora en la universidad [Academic literacy \& ICT. A reading promotion experience at university]. Revista Educación social, 59, 24-38. https://dialnet.unirioja.es/servlet/articulo?codigo=7056866

Saunders, J. C., \& Huynh, H. (1980). Consideration for sample size in reliability studies for mastery tests. Publication series in mastery testing. Annual Meeting of the Eastern Educational Research Association, Norfolk, VA, USA.

Scott, C. L. (2015). El futuro del aprendiraje 2 ¿Qué tipo de aprendiraje se necesita en el siglo XXI? [The Future of Learning 2 What kind of learning is needed in the 21st century?]. Investigación \& Prospectiva en Educacion. UNESCO [Documentos de Trabajo ERF, No. 14]

Silber-Varod, V., Eshet-Alkalai, Y., \& Geri, N. (2019). Tracing research trends of 21stcentury learning skills. British Journal of Educational Technology, 50(6), 3099-3118. https://doi.org/10.1111/bjet.12753

Somekh B. (2008). Factors affecting teachers' pedagogical adoption of ICT. In J. Voogt \& G. Knezek (Eds), International handbook of information technology in primary and secondary education (pp. 449-460. Springer. https://doi.org/10.1007/978-0-387-73315-9 27

Stensaker, B., Maassen, P., Borgan, M., Oftebro, M., \& Karseth, B. (2007). Use, updating and integration of ICT in higher education: Linking purpose, people and pedagogy. Higher Education, 54(3), 417-433. https://doi.org/10.1007/s10734-006-9004-x

Tapia, C., Navarro, Y., \& De la Serna, A. S. (2017). El uso de las TIC en las prácticas académicas de los profesores de la Benemérita Universidad Autónoma de Puebla [The use of ICTs in the academic practices of the professors of the Benemérita Universidad Autónoma de Puebla]. Revista Electrónica de Investigación Educativa, 19(3), 115-125. https://doi.org/10.24320/redie.2017.19.3.1270

Thorndike, R. (1995). Book review: Psychometric theory (3rd ed.) by Jum Nunnally and Ira Bernstein. New York: McGraw-Hill. 1994, XXIV+752 pp. Applied Psychology Measurement, 19(3), 303-305. https://doi.org/10.1177/014662169501900308 
Trends in Using ICT Resources by Professors in HEIs

Tok, B. R., \& Sora, M. (2013). Perspective of emerging integrating technology (ICT) in learning and teaching. International Journal of Information and Education Technology, 3(2), 282-285. https://doi.org/10.7763/IJIET.2013.V3.281

Torres, J., Duart, J., \& Hinojosa-Becerra M. (2018). Plagio, uso de Internet \& éxito académico en la Universidad [Plagiarism, internet and academic success at the university]. Journal of New Approaches in Educational Research, 7(2), 106-112. https://doi.org/10.7821/naer.2018.7.324

Trizano-Hermosilla, I., \& Alvarado, J. M. (2016). Best alternatives to Cronbach's alpha reliability in realistic conditions: congeneric and asymmetrical measurements. Frontiers in Psychology, 7. https://doi.org/10.3389/fpsyg.2016.00769

Trujillo, F. (2014). Artefactos digitales: una escuela digital para la educación de hoy Digital Artifacts: a digital school for today's education]. Graó.

Ungar, O., \& Baruch, A. (2016). Perceptions of teacher educators regarding ICT implementation. Interdisciplinary Journal of e-Skills and Lifelong Learning, 12, 279-296. https://doi.org/10.28945/3606

Vázquez-Cano, E., \& Sevillano-García, M. (2015). El smartphone en la educación superior. Un estudio comparativo del uso educativo, social \& ubicuo en universidades españolas e hispanoamericanas [The smartphone in higher education. A comparative study of educational, social \& ubiquitous use in Spanish and Latin American universities]. Signo \& Pensamiento, XXXIV (67),114-131. https://www.redalyc.org/pdf/860/86043044007.pdf

Ventura-León, J. L., \& Caycho-Rodríguez, T. (2017). El coeficiente Omega: un método alternativo para la estimación de la confiabilidad [The Omega Coefficient: An alternative method for estimating reliability]. Revista Latinoamericana de Ciencias Sociales, Niñez \& Juventud, 15(1), 625-627. https://www.redalyc.org/pdf/773/77349627039.pdf

Voogt, J., \& Roblin, N. P. (2012). A comparative analysis of international frameworks for $21^{\text {st }}$ century competences: Implications for national curriculum policies. Journal of Curriculum Studies, 44(3), 299-321. https://doi.org/10.1080/00220272.2012.668938

Ward, M. (2011, 2 November). ¿Tienen futuro los computadores de escritorio? BBC News [Do desktop computers have a future? BBC News]. https://www.bbc.com/mundo/noticias/2011/11/111101 tecnologia futuro pes tsb

Watson, W. R., Watson, S. L., \& Reigeluth, C. M. (2015). Education 3.0: Breaking the mold with technology. Interactive Learning Environments, 23(3), 332-343. https://doi.org/10.1080/10494820.2013.764322

Yang, Y., \& Green, S. B. (2011). Coefficient alpha: A reliability coefficient for the 21st Century? Journal of Psychoeducational Assessment, 29, 377-392. https://doi.org/10.1177/0734282911406668

Yurdugul, H. (2008). Minimum sample size for Cronbach's coefficient alpha: A Monte-Carlo study. Journal of Education, 35, 397-405. https://www.researchgate.net/publication/268809872 Minimum Sample Size for Cronbach's Coefficient Alpha A Monte Carlo Study

Zapata, M. (2012). Recursos educativos digitales: conceptos básicos [Digital Educational Resources: The Basics]. http://aprendeenlinea.udea.edu.co/boa/contenidos.php/d211b52ee1441a30b59ae008e2d31386/845/estilo/aHR0cDovL2FwcmVuZGVlbmxpbmVhLnVkZWEuZWR1LmNvL2VzdGlsb3MvYXp1bF9jb3Jwb3 LhdG12by $5 j \mathrm{c} 3 \mathrm{M}=/ 1 /$ contenido/

Zhao J., Yao P., \& Kong J. (2016). Comparative study on international policies for teachers' ICT capacity-building. In R. Huang, Kinshuk, \& J. Price J. (Eds.), ICT in education in global context. Lecture notes in educational technology (pp. 267-293). Springer. https://doi.org/10.1007/978-3-662-47956-8 14 


\section{BIOGRAPHIES}

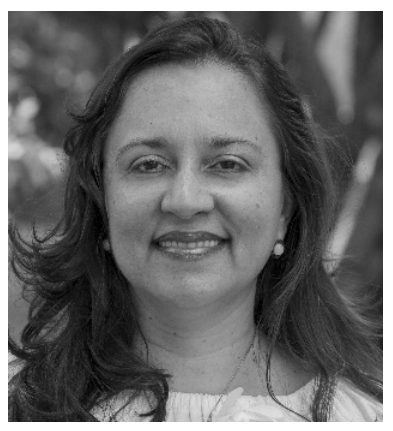

Carmen Ricardo Barreto is a Systems Engineer from Universidad del Norte (Colombia) and a Ph.D. in Education from Universidad Nacional Abierta \& a Distancia (UNED). She is currently the Head of the Education Department, Coordinator of the emphasis on Media Applied to Education in the Master's Degree of Education. She is a member of the Educational Informatics research group at the same institution. Her research interests are design of learning environment using ICT (online learning, b-learning and enhance environment using ICT), Strategic Planning to integrate ICT in the areas of educational management, Intercultural Education and intercultural competences in faculty and students. Dr. Ricardo teaches in graduate and postgraduate programs, some courses are: "E-learning", "Design of Online learning Environments", "Intercultural Education", "Planning and organization of ICT", "Educational Mediation with ICT", "Project Educational Planning", "Curriculum Design of B-learning Environments" and "Educational Project Management". She was involved in many projects related to ICT an intercultural education on preschool, primary, secondary and higher education. She has been a students advisor master's and doctorate research projects. She has been a lecturer in a national and international conferences and published papers, chapter of books and books as a result of researches

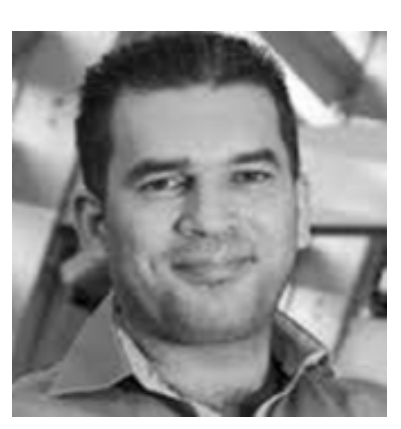

Daladier Jabba Molinares has a degree in Systems Engineering. He has a Ph.D. in Computer Science and Engineering, Msc. in Computer Engineering, University of South Florida-Tampa, and Msc in Computer Science from UNAB, Colombia. Professor Jabba is the International Resources Manager R \& D at the Research, Development and Innovation Department, and an Associate Professor of the Systems Engineering Department at Universidad del Norte. He is a member of the Research Group on Computer Networks and Software Engineering - GReCIS. He has more than 40 papers published in different journals and 10 publications in books and book chapters. Professor Jabba works in projects with University-Industry interaction, and he has belonged to the National Committee that designs templates to develop the questions in the tests named Saber Pro for students of final semesters in Colombian universities. He was part of the group of researchers belonging to the technical secretariat of the Universidad del Norte in support of the "Mission of Wise Men" appointed by the Colombian government in 2019, in the focus of Industry 4.0.

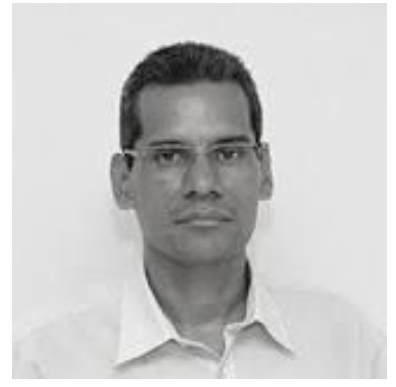

Dr. rer. nat. Humberto Llinás has a degree in Education Sciences, with emphasis in Mathematics, Physics and Statistics from the Universidad del Atlántico (Colombia). He holds a M. A. in Math. He is Doctor in Statistics from the Johannes Gutenberg University of Mainz (Germany). Nowadays he belongs to two (2) research groups. He has in his track record the publication of eight (8) books and 27 papers in national and international journals, on different fields of knowledge. During 2008-2019 he has presented three (3) projects financed by the Research and Projects Direction (Dirección de Investigación \& Proyectos DIDI) in Universidad del Norte, 3 more financed by Colciencias (Colombia) and 1 more financed by OPS. He has supervised 17 students in Postgraduate Programs in Applied Statistics to the completion of their degrees (2004-2019). 


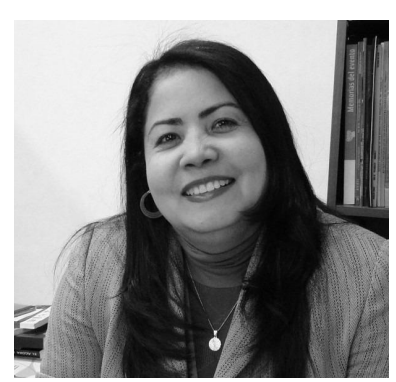

Judith Peña Santodomingo has a degree in Psychopedagogy from Universidad de la Costa. Master in Education, emphasais on curriculum, from the Universidad del Norte-Universidad Javeriana. She is currently the Head of the Interdisciplinary Center for Humanistic Studies -CIDEH at Universidad San Buenaventura (Medellin, Colombia). She is a member of GIDPAD research group of the same institution. She has 30 years of experience as teacher at different educational levels: at university level in undergraduate and graduate programs in areas such as research, educational psychology, curriculum, pedagogy and supervision of teaching practices; at pre-school, basic and secondary school level, as well as, in the development of research projects in technological and educational contexts.

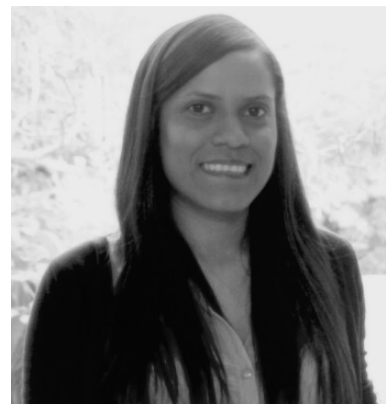

Cinthia Astorga Acevedo is a Bachelor in Children Pedagogy and Master in Education with emphasis on Media applied to education from Universidad del Norte (Colombia). Professor and researcher of the Education Department at Universidad del Norte. Author of academic publications related to educational technology, educational assessment, and curricular integration of ICT in different educational contexts. Active researcher of the research groups Educational Computing and Cognition and Education at Universidad del Norte.

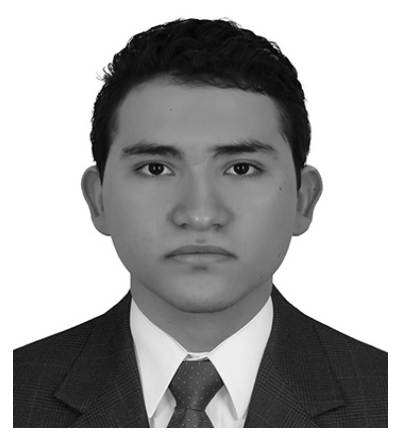

Pedro Acevedo Rodríguez is currently a Systems Engineer and master's student from the Universidad del Norte, Barranquilla, Colombia. His research interests include wireless sensor networks, graph theory, Software development in educational context, and cryptography.

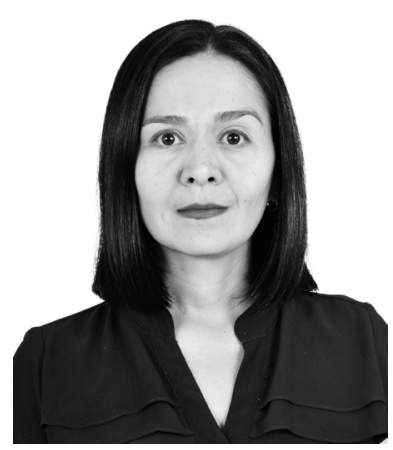

Claudia Baloco Navarro, is a Systems Engineer, Mg, in Education and currently pursuing a Ph.D. in Education at Universidad del Norte (Barranquilla, Colombia). Her research project is carried out in the Educational Computer Science research group. She has worked as a professor at Universidad Simon Bolivar and as the Head of the Systems Engineer Program at Universidad de la Costa. She joined Universidad del Atlántico in 2008 as a professor and has been associated professor since 2015. Her research interests include technologies applied to education, e-learning, MOOC, instructional design, learning objects and creation of virtual learning environments. ORCID: 0000-0003-3229-2338 


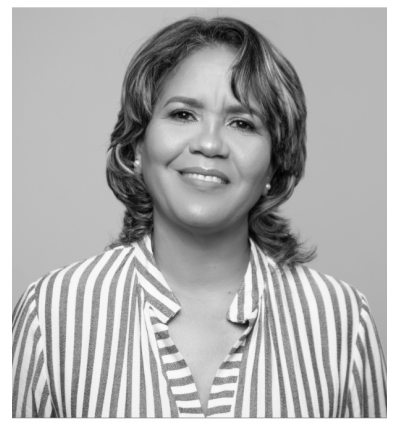

Sandra Villarreal Villa has a degree in Biology and Chemistry. Specialist in University Teaching, Specialist in Telematics and Computing, Mg. In Education and currently pursuing doctoral studies at Universidad del Norte (Barranquilla, Colombia). Her research project is carried out in the Educational Computer Science research group. She has worked as a fulltime profesor and as Dean of the faculty of Humanities and research professor at Universidad de la Costa. She joined Universidad del Atlántico in 2019 as a research professor. Her research line: ICT applied to education, and publications related to teacher transformation in virtual learning environments. 